\title{
ACE2 as a Therapeutic Target for COVID-19; Its Role in Infectious Processes and Regulation by Modulators of the RAAS System
}

\author{
Veronique Michaud ${ }^{1,2}$, Malavika Deodhar ${ }^{1}$, Meghan Arwood ${ }^{1}$, Sweilem B Al Rihani ${ }^{1}$, \\ Pamela Dow ${ }^{1}$ and Jacques Turgeon 1,2,*(D) \\ 1 Tabula Rasa HealthCare Precision Pharmacotherapy Research \& Development Institute, Orlando, FL 32827, \\ USA; vmichaud@trhc.com (V.M.); mdeodhar@trhc.com (M.D.); marwood@trhc.com (M.A.); \\ srihani@trhc.com (S.B.A.R.); pdow@trhc.com (P.D.) \\ 2 Faculty of Pharmacy, Université de Montréal, Montreal, QC H3C 3J7, Canada \\ * Correspondence: jturgeon@trhc.com; Tel.: +856-938-8793
}

Received: 11 June 2020; Accepted: 2 July 2020; Published: 3 July 2020

\begin{abstract}
Angiotensin converting enzyme 2(ACE2) is the recognized host cell receptor responsible for mediating infection by severe acute respiratory syndrome coronavirus 2 (SARS-CoV-2). ACE2 bound to tissue facilitates infectivity of SARS-CoV-2; thus, one could argue that decreasing ACE2 tissue expression would be beneficial. However, ACE2 catalytic activity towards angiotensin I (Ang I) and II (Ang II) mitigates deleterious effects associated with activation of the renin-angiotensin-aldosterone system (RAAS) on several organs, including a pro-inflammatory status. At the tissue level, SARS-CoV-2 (a) binds to ACE2, leading to its internalization, and (b) favors ACE2 cleavage to form soluble ACE2: these actions result in decreased ACE2 tissue levels. Preserving tissue ACE2 activity while preventing ACE2 shredding is expected to circumvent unrestrained inflammatory response. Concerns have been raised around RAAS modulators and their effects on ACE2 expression or catalytic activity. Various cellular and animal models report conflicting results in various tissues. However, recent data from observational and meta-analysis studies in SARS-CoV-2-infected patients have concluded that RAAS modulators do not increase plasma ACE2 levels or susceptibility to infection and are not associated with more severe diseases. This review presents our current but evolving knowledge of the complex interplay between SARS-CoV-2 infection, ACE2 levels, modulators of RAAS activity and the effects of RAAS modulators on ACE2 expression.
\end{abstract}

Keywords: ACE2; SARS-CoV-2; renin-angiotensin-aldosterone system; angiotensin II converting enzyme inhibitors; angiotensin II type 1 receptor blockers; pneumonia

\section{Introduction}

In late December 2019, several local health facilities in Wuhan City, Hubei Province of China, reported clusters of patients with pneumonia of an unknown etiology [1]. On 31 December 2019, the Chinese Center for Disease Control and Prevention (China CDC) dispatched a rapid response team to accompany Hubei provincial and Wuhan City health authorities; their mandate was to conduct an epidemiologic and etiologic investigation of the situation that appeared to be linked to a seafood and wet animal whole sale market [1]. In the first days of January 2020, Chinese scientists identified severe acute respiratory syndrome coronavirus 2 (SARS-CoV-2) as the responsible pathogen; a rapid sequencing of its RNA was also performed [2,3]. SARS-CoV-2 quickly spread in China and globally, causing the coronavirus disease 2019 (COVID-19) pandemic [4,5]. At the time this review was written (24 June 2020), COVID-19 has been diagnosed in more than 9,293,272 patients world-wide, has been associated with over 478,221 deaths, and has been considered a global health threat [6]. 
Soon after its outbreak, clinical features associated with COVID-19 started to be known. As of 2 January 2020, symptoms observed in 41 patients were fever $(98 \%)$, cough $(76 \%)$, myalgia and fatigue (44\%) [7]. Similar observations were made following extraction of data from 1099 patients with laboratory-confirmed COVID-19 from 552 hospitals in 30 provinces in mainland China through 29 January 2020 [8]. The disease-causing capacity of this virus, along with its mortality rates-ranging from 0.1 to $15.4 \%$-have raised concerns worldwide [1,6]. Clinical reports and epidemiological data related to COVID-19 indicate that older individuals with specific comorbidities have an increased risk of infection, potentially developing more severe symptoms, all of this resulting in higher mortality rates [9]. Hypertension, diabetes, and cardiovascular diseases seem to be the most frequent comorbid conditions in patients with COVID-19 [10,11]. Furthermore, concerns regarding the use of specific anti-hypertensive medications such as modulators of the renin angiotensin-aldosterone system (RAAS) and susceptibility to SARS-2-CoV infection have been raised and discussed [12-18]. Finally, a significant decrease in adherence to several drug classes_including RAAS modulators, antilipidemic and antidiabetic agents- has been observed since the beginning of the COVID-19 pandemic amidst an unrealistic optimism towards the pandemic, especially in men $[19,20]$.

In this review, the interplay between SARS-CoV-2 infection, angiotensin converting enzyme 2 (ACE2) levels and modulators of the RAAS activity, as well as the effects of RAAS modulators on ACE2 expression, is addressed. A summary of the current knowledge as it pertains to the efficacy and safety of RAAS modulators in patients with all-cause pneumonia and underlying cardiovascular comorbidities is also presented.

\section{Literature Search Strategy}

We performed a systematic literature review from PubMed with significant keywords including COVID-19 and ACE2 (675 hits), COVID-19 and RAAS (52 hits), COVID-19 and ACE inhibitors (223 hits), COVID-19 and ARBs (71 hits), COVID-19 and mineralocorticoid inhibitors (6 hits), ACE2 and ACE inhibitors (1073 hits), ACE2 and ARBs (55 hits), ADAM17 and ACE2 (43 hits). From these 2197 publications, 220 references were retained and cited in the manuscript as major and primary sources of information. We also used our literature search daily to detect new publications and maintain our website as a source of information (https://trhc.spprdi.com/covid19/). Relevant and most recent publications were reviewed and information was extracted.

\section{SARS-CoV-2}

Coronaviruses, a part of the large Coronaviridae family, are large and enveloped viruses with single-stranded, positive-sense RNA genomes [21-23]. To date, seven coronaviruses have been identified and are known to cause diseases in humans (HCoVs) $[24,25]$. Coronaviruses are classified into four genera: Alpha, Beta, Gamma, and Delta [26]. HCoV-229E and HCoVNL63 belong to the Alphacoronavirus genus, while the Betacoronavirus genus includes HCoV-HKU1, HCoV-OC43, MERS-CoV (Middle Eastern Respiratory Syndrome), SARS-CoV, and the novel SARS-CoV-2. HCoV-NL63, HCoV-229E, HCoV-OC43, and HCoV-HKU1 are usually the cause of common colds, and in some cases cause severe lower respiratory tract infections [27]. Additionally, HCoV-NL63 infections are linked with croup (laryngotracheitis), while HCoV-OC43 infections are associated with severe lower respiratory tract infections in children $[24,28,29]$. The highly pathogenic SARS-CoV, MERS-CoV and SARS-CoV-2 are all zoonotic in origin, while the four low-pathogenicity coronaviruses (HCoV-NL63, HCoV-229E, HCoV-OC43, and HCoV-HKU1) are endemic in humans [30,31].

Initiation of viral infections involves the binding of a virus particle to host surface cellular receptors. Complete and comprehensive reviews of $\mathrm{HCoV}$ infectious processes have been reported [26,32,33]. In brief, for $\mathrm{HCoVs}$, the process of activation (trigger for coronavirus to fuse membranes) and cellular entry is mediated by the surface-located spike (S) glycoprotein [26,34]. SARS-Co-V S protein is activated either by (1) lysosomal proteases (cathepsin L, cathepsin B) after endocytosis of the viral particle, or (2) extracellular proteases (e.g., elastases in the respiratory tract) for circulating viruses; or (3) by 
cell surface proteases (e.g., Type II transmembrane serine protease (TMPRSS2) on the surface of lung cells) [26,35-42]. The $S$ protein comprises two functional subunits: subunit $S 1$ binds to a receptor on the host cell surface for viral attachment, while subunit S2 fuses the host and viral membranes, allowing viral genomes to enter host cells $[26,30]$.

Coronaviruses show different patterns of selective binding to host receptors. For example, SARS-CoV viruses (including SARS-CoV-2) specifically bind to the zinc-containing peptidase ACE2 (Figure 1) [43-47]. SARS-CoV binding does not interfere with the enzymatic activity of ACE2, nor does the enzymatic activity of ACE2 play any role in SARS-CoV entry [48]. The ACE2-virus complex is then translocated to endosomes where endosomal acid proteases cleave the $S$ protein, activating its fusion and release of the viral genome [46,49-52]. Viral entry of SARS-CoV-2 via ACE2 receptors leads to pneumonia, acute myocardial injury, and chronic damage to the cardiovascular system [53,54]. Recently, nasal gene expression of ACE2 has been shown to be lower in children than in adults, which may explain age-related differences in the risk associated with SARS-CoV-2, at least for upper respiratory tract infections [55].
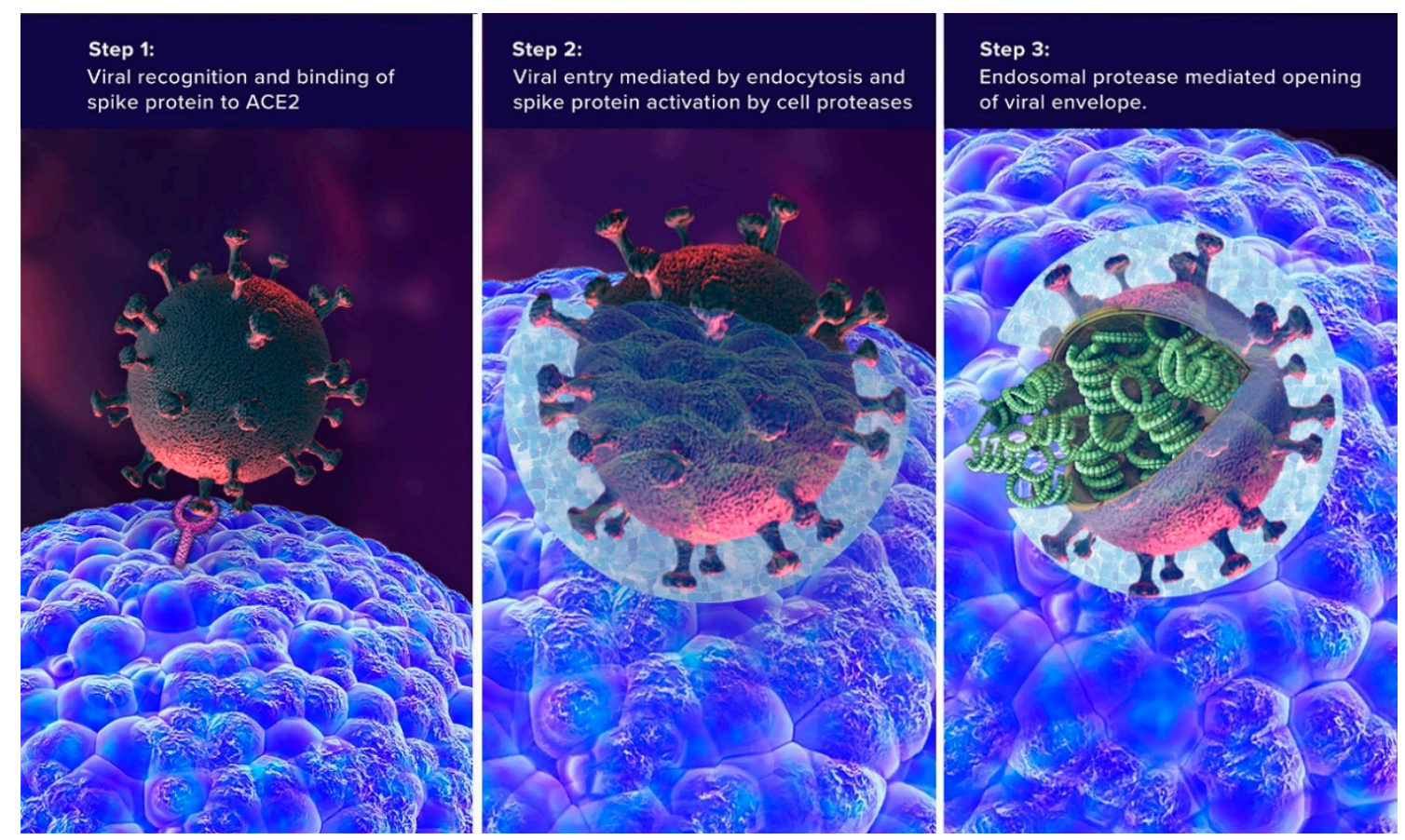

Figure 1. Interaction between ACE2 receptor and the SARS-CoV-2 virus (Contributed by Malavika Deodhar. Designed by Ernesto Lucio.)

Though SARS-CoV and SARS-CoV-2 share a common mechanism for entry into the cell, SARS-CoV-2 differs from SARS-CoV by substitutions in 380 amino acids [56]. There are 14 critical amino acids for ACE2 binding in the receptor-binding domain (RBD) of SARS-CoV-2, of which 6 differ between SARS-CoV-1 and SARS-CoV-2 [30]. These alterations provide improved hydrophobic interactions and salt bridge formations, making the binding affinity between SARS-CoV-2 and ACE2 stronger than the original SARS-CoV. Stronger binding could be an underlying factor explaining the larger global impact of COVID-19 compared to the SARS pandemic in 2003 [57,58]. Blocking the binding of SARS-CoV-2 to human ACE2 by interfering with the RBD of the viral S-protein could be a potential therapeutic target [59].

\section{The Renin-Angiotensin-Aldosterone System (RAAS)}

Significant research initiatives have created a better understanding of both the complexity of the RAAS and the involvement of multiple enzymes and receptors in these pathways (Figure 2) $[60,61]$. 
Over the last century, we have learned that RAAS is stimulated by hypotension, ultimately resulting in the production of angiotensin II (Ang II or Ang-1-8) to increase blood pressure via multiple pathways. Renin is a proteolytic enzyme that cleaves angiotensinogen in plasma to angiotensin I (Ang I or Ang-1-10). Ang I further cleaves to Ang II via the angiotensin converting enzyme (ACE). The biologically active peptide, Ang II, acts on angiotensin type I and type II receptors (AT1R and AT2R). Binding of Ang II to AT1R promotes vasoconstriction, inflammation, renal sodium and water reabsorption and oxidative stress [62]. From the mid-1980s, research has recognized that a local autocrine/paracrine RAAS exists in a number of tissues which may play a significant role in regulating locally (tissue) vs. systemically (serum) the RAAS [63-65]. Collectively, these discoveries have stimulated the development of therapies targeting various proteins in the RAAS [66].

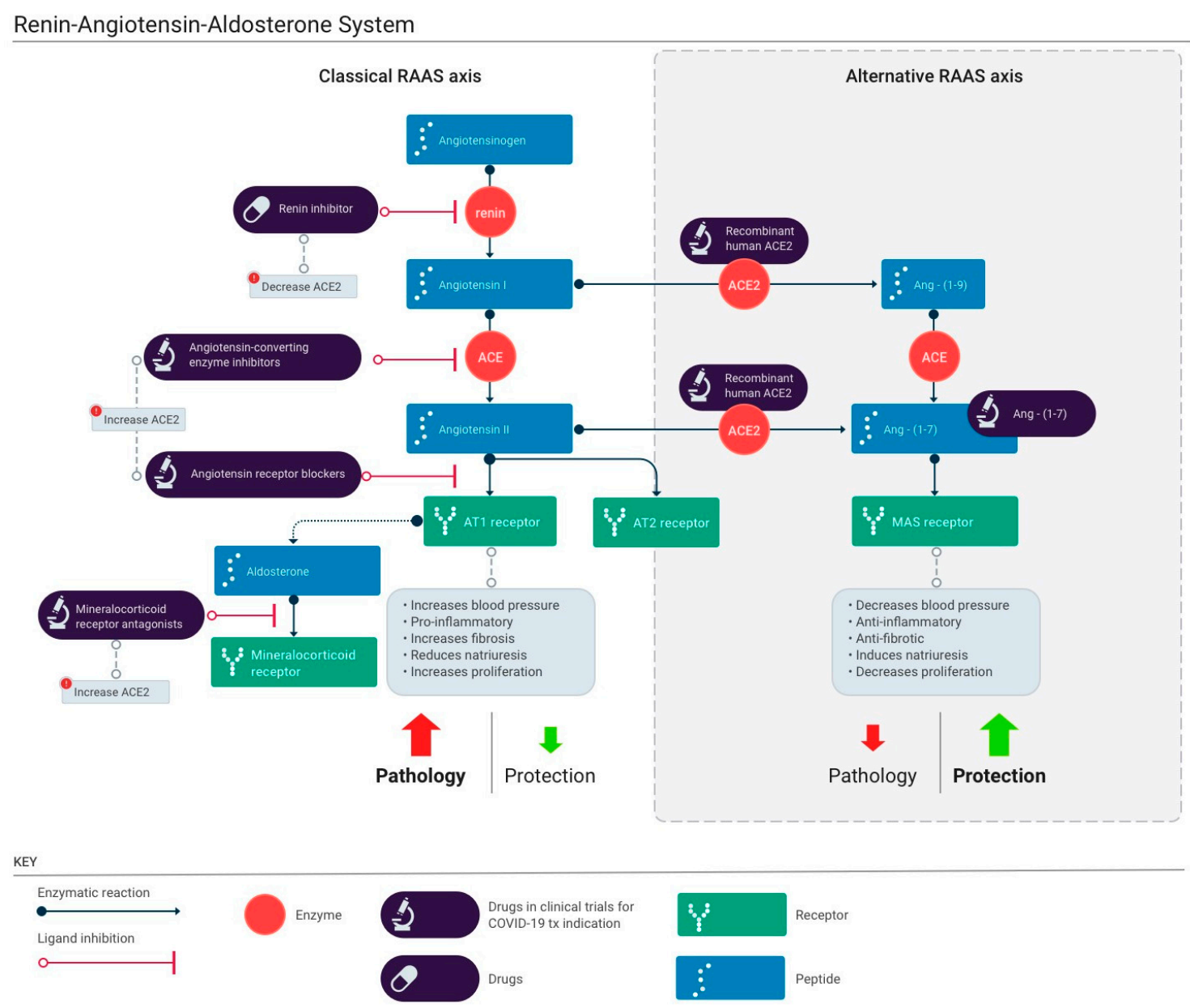

Figure 2. The renin-angiotensin-aldosterone system (RAAS) cascade, RAAS modulator actions and their potential impacts on ACE2 (Contributed by Malavika Deodhar, designed by Ernesto Lucio.)

\section{Role of ACE2 in the RAAS}

ACE2 is an important constituent of the RAAS and, as mentioned previously, is essential for the entry of SARS-CoV-2 into cells [44,46,67-69]. Recent data obtained from COVID-19 patients has demonstrated a significant increase in Ang II levels, which was linearly and positively correlated with both viral load and lung injury [70]. With elevated levels, more Ang II is available to bind to the AT1R, thereby mediating increased vasoconstriction, inflammation, and lung vascular permeability [71,72].

Detrimental effects associated with the overstimulation of the Ang II/AT1R axis have spurred research for a counter-regulatory axis of the activated RAAS. ACE2 is a RAAS regulator able to mitigate the detrimental actions mediated by Ang II and AT1R activation [73]. ACE2, a membrane-bound 
carboxypeptidase, has a fundamentally protective role in regulating cardiovascular and renal functions [74]. ACE2 is a homolog of ACE, with the catalytic domains of both peptides sharing approximately 40\% identity [74,75]. While ACE increases the production of Ang II, ACE2 reduces it. This is achieved via two mechanisms (Figure 2). First, ACE2 shuttles the conversion of Ang I to Ang-(1-9), instead of Ang II [73,74]. Second, ACE2 directly acts on Ang II and converts it to the vasodilator Ang-(1-7). As a result, ACE2 acts to increase production of Ang-(1-7) at the expense of Ang II. Ang II acts through AT1Rs and AT2Rs, while Ang-(1-7) mediates its effects via Mas receptors (MasR), exerting vasodilatory and anti-proliferative effects $[68,76]$. Other protective effects of the ACE2/Ang-(1-7)/MasR axis include reductions in the release of pro-inflammatory cytokines and both anti-fibrotic and anti-hypertrophic effects [77].

While ACE expression is ubiquitous in the body, ACE2 shows a more restricted distribution [78,79]. ACE2 is expressed specifically in the heart, kidneys, testes, gastrointestinal tract (esophagus, enterocytes of the small intestine and colon), arterial and venous endothelial cells, lungs, cholangiocytes, and bladder [75,80-85]. The tissue expression and distribution of ACE2 could help delineate the potential infection routes of SARS-CoV-2, as the main targets of SARS-CoV-2 are the lungs, immune organs, and systemic small vessels. At the same time, ACE2 distribution is large enough to explain the increased potential for multiple organ damage or failure as a consequence of SARS-CoV-2 infection [80].

In 2004 and 2005, Hamming et al. and Jia et al. studied the host-pathogen interactions of SARS-CoV and NL63 coronavirus and reported that ACE2 protein was expressed in human airway epithelia and in lung parenchyma $[82,86]$. It was shown that the ACE2 protein was more abundantly expressed on the apical side than the basolateral side of polarized airway epithelia, which could favor viral entry from respiratory droplets [86]. ACE2 expression in the lung was also confirmed in recent single cell RNA-seq analysis performed on lung tissue donated from eight healthy adults [87]. This study demonstrated that $83 \%$ of lung cells expressing ACE2 were alveolar epithelial type II cells. It also suggests that alveolar cells can serve as a reservoir for SARS-CoV-2 infection, corroborating previous evidence [82]. ACE2 receptors being found in cells in the lower lung can explain the high incidence of pneumonia and bronchitis in patients with severe SARS-CoV-2 infection, though its physiological role in the airway is currently unknown.

High ACE2 RNA levels have also been identified in oral mucosa (especially in epithelial cells of the tongue) [88]. Case reports indicate sensory impairments in patients tested positive for SARS-CoV-2; loss of smell and loss of taste have anecdotally been observed in a significant number of patients [89]. A pilot study showed that rectal specimens have tested positive for SARS-CoV-2 (4 out of 62); the virus was also detected in the gastrointestinal tract, saliva, or urine [8,90]. Tissue expression of ACE2 may explain some extrapulmonary manifestations, such as gastrointestinal symptoms observed with HCoV infections like watery diarrhea [91,92].

Beside its expression in specific tissues, ACE2 is also observed in plasma. Proteolytic cleavage of the membrane bound ACE2 into the soluble form is in part dependent of the enzyme ADAM17 [93,94]. Cleavage of tissue ACE2 would result in a loss of ACE2 protection against tissue RAAS by decreasing the compensatory potential of ACE2. ADAM17 activity is thought to be higher in men than women [95]. Studies have shown that SARS-CoV viruses activate ADAM17, thus explaining increased plasma levels of ACE2 observed in patients with SARS and COVID-19 [96]. Activation of ADAM17 is damaging since, (1) it reduces the levels and cardioprotective effects of ACE2 in tissues, and (2) it triggers an uncontrolled inflammatory response [97]. As opposed to the tissue-bound ACE2, the role of the circulating soluble ACE2 is not fully known. The increase in circulating soluble ACE2 might represent a pathological shift of ACE2 from its "normal" tissue membrane location.

\section{ACE2 Regulation}

Evidence suggests that ACE2 is regulated by various pathways [98,99]. Though evidence for the coregulation of ACE and ACE2 levels is not robust, studies have suggested a close relationship 
between Ang II levels and ACE2 expression [100]. For instance, disease states involving dysregulation of the RAAS have been reported to play a role in regulating ACE2 levels [101,102]. Plasma levels of ACE2 are reported to be very low or undetectable in healthy subjects, but in the presence of cardiovascular diseases, a significant increase in ACE2 levels was observed [96,101]. Alterations in the RAAS axis are believed to be critical for the development of diabetic nephropathy (micro- and macro-vascular complications) $[103,104]$. For example, in diabetic renal tubules, ACE2 gene expression is decreased by approximately $50 \%$, which is associated with reduced Ang-(1-7) formation and Ang II accumulation [83].

Sex-related differences have been observed between men and women in mortality rates from SARS-CoV and SARS-CoV-2; the death rate is higher in men than in women $[105,106]$. This difference could be attributed to increased ACE2 expression in men, leading to ACE2 plasma levels that are higher in men than in women [96]. Differences between men and women could also be related to a genetic polymorphism in $A C E 2$. Recessive $A C E 2$ polymorphisms predisposing men to infection could be silenced in women as ACE2 is located on the $\mathrm{X}$ chromosome in the human genome (if only one $\mathrm{X}$ chromosome is affected) [67]. Indeed, several studies have reported that ACE2 genetic polymorphisms can play a role in cardiovascular diseases, particularly in gender-related hypertension susceptibility $[107,108]$. ACE2 polymorphism could also explain in part ethnic differences observed in COVID-19 disease prevalence and severity [109]. For instance, East Asian populations were found to have much higher allele frequencies in the expression quantitative trait locus variants associated with higher ACE2 expression in tissues than other populations; other variants also showed important inter-ethnic differences [110]. Finally, some genetic variants observed in ACE2 leading to variations in the intermolecular interactions with the viral S-protein may confer resistance [109].

Other studies have suggested an involvement of aldosterone and estrogens in regulating ACE2 expression [99,111]. Evidence supports that estrogens can modify the local RAAS homeostasis via the downregulation of ACE and simultaneous upregulation of ACE2, AT2R, and MasR expression levels $[107,112]$. Finally, data from animal experiments conducted with infected SARS-CoV mice suggest that estrogen receptor signaling plays a pivotal role for protection in females [113].

\section{Blocking or Enhancing ACE2?}

ACE2 is an important regulator of the immune response, especially inflammation [114]. A 2014 study found that the ACE2 enzyme offers protection against lethal avian influenza [115]. In acute lung injury, ACE, Ang II, and the AT1R function as lung injury-promoting factors, while the negative regulation of Ang II levels by ACE2 protects against lung injury [71,116-126]. Paradoxically, ACE2 is identified as a functional receptor essential for SARS infections [114]. The burden of viral replication triggers the immune response through a downregulation of ACE2 expression by SARS-CoV S-protein, leading to pathogenesis of severe acute lung injury [72,127,128]. So, even though ACE2 facilitates SARS-CoV-2 entry in pulmonary epithelial cells, ACE2/Ang-(1-7) axis stimulation could mitigate SARS-induced pulmonary injuries and the severity of damage [114]. ACE2 internalization by SARS-CoV-2 could potentially result in the loss of ACE2 at the cell surface, canceling a major pathway for the cell to degrade Ang II and generate Ang-(1-7) [71,72,129]. Subsequently, ACE2 reduction due to its internalization may increase the Ang II/Ang-(1-7) ratio, which may worsen the pulmonary damage first triggered by the SARS-CoV-2 infection. At lung level, such dysregulation could ease the progression of inflammatory and hyper-coagulation responses that are reliant on local overactivity of Ang II, inefficiently counterbalanced by Ang-(1-7) [114]. For instance, in vivo data in SARS-CoV infected mice revealed exacerbation in acute lung failure by the downregulation of ACE2 expression [72]. In addition to lung injury seen in COVID-19 patients, SARS-CoV-2 has been shown to cause acute myocardial injury, the mechanism of which may be related to ACE2 since ACE2 is highly expressed in the heart [130].

The general cardioprotective role of ACE2 has limited the development of ACE2 inhibitors because they are unlikely to be of therapeutic benefit in cardiovascular disorders where the upregulation of 
ACE2 expression and activity is beneficial. Even so, a number of ACE2 selective inhibitors have been developed, including MLN-4760 (GL1001), DX-600, and 416F2 [131-133]. On the contrary, ACE2 activators, such as xanthenone, have been tested in a heart failure rat model [134]. Xanthenone has been demonstrated to decrease blood pressure and improve cardiac function in spontaneously hypertensive rats. However, the potential therapeutic effects of ACE2 activators or analogs needs to be further investigated since antibodies against ACE2 have been detected in human plasma and development of autoantibodies to ACE2 may be associated with detrimental effects such as constrictive vasculopathies [135].

\section{ACE Inhibitors}

In the mid-1970s, the search for a potent, orally active, ACE inhibitor led to the synthesis of captopril by researchers at E.R. Squibb \& Sons Pharmaceuticals [136]. This was followed by the synthesis and introduction to the market of a series of other ACE inhibitors with various pharmacokinetic and pharmacodynamic properties [137].

In the mid-1980s, the concept of two classes of ACE systems-serum ACE and tissue-specific ACE-was introduced [63-65]. The presence of angiotensin and renin messenger RNA (mRNA) was demonstrated in 12 different extrahepatic tissues of rats, strongly suggesting that there is local synthesis of angiotensinogen and renin $[138,139]$. Similar to the systemic ACE system (involving angiotensinogen released from the liver, its serum conversion into Ang I by renin released from the kidneys and, through a passage into the pulmonary vasculature, the conversion of Ang I into Ang II), tissue RAAS is capable of both local generation and action of Ang II [140-143]. Numerous studies, including large clinical trials, have demonstrated the greater value of tissue ACE inhibition vs. serum ACE inhibition in patients with hypertension, diabetes, renal disease, and heart failure [144]. Drug biophysical characteristics were tentatively associated with increased affinity for ACE, as carboxyl-containing ACE inhibitors (enalapril, lisinopril, trandolapril, ramipril, quinapril, perindopril) were demonstrated to bind more strongly to the zinc ligand than sulphydryl-containing (captopril) or phosphoryl-containing (fosinopril) ACE inhibitors [145]. More importantly, ACE inhibitors lipophilicity was associated with greater selectivity and affinity for tissue ACE: the drug lipophilicity is ranked captopril $<$ lisinopril < enalapril $<$ perindopril $<$ ramipril $<$ quinapril $<$ trandolapril $<$ fosinopril [144] .

\section{Angiotensin Receptor Blockers (ARBs)}

As mentioned previously, Ang II actions are mediated by binding mostly to two receptors, AT1R and AT2R [146]. These receptors are members of the G protein-coupled receptor family and interact with specific G-proteins, leading to the activation of special effector systems.

Saralasin (a partial agonist) and other Ang II peptide analogues were studied as potential ARBs [147-149]. Due to their poor bioavailability, molecular modeling strategies were used to derive orally active, potent, and selective nonpeptide ARBs. At least eight ARBs have been introduced into clinical practice: losartan, valsartan, azilsartan, candesartan, eprosartan, irbesartan, olmesartan, and telmisartan. They differ in their affinity for the AT1R (Kd from $2 \mathrm{nM}$ (irbesartan) to $10 \mathrm{nM}$ (losartan)), their selectivity for AT1 and AT2 receptors (from 1000:1 (losartan) to 30,000:1 valsartan)), their biological half-life (from 5h (eprosartan) to $24 \mathrm{~h}$ (telmisartan)), and their metabolism (mostly involving CYP2C9 for losartan, candesartan, irbesartan, azilsartan, and valsartan, while olmesartan is a substrate of SLCO1B1 (which may impact its tissue distribution) [150,151].

\section{Mineralocorticoid Receptor Antagonists}

Antimineralocorticoids including spironolactone and eplerenone, are potassium-sparing diuretics that block the effects of aldosterone on the mineralocorticoid receptors. Mineralocorticoid receptors are expressed in epithelial and non-epithelial tissues including kidney, salivary gland, airway epithelia, gut, brain, hypothalamus, heart, and others [62,152-154]. Spironolactone and eplerenone can block both epithelial and non-epithelial actions of aldosterone [155]. Compared to spironolactone, eplerenone is a 
next-generation aldosterone antagonist selective for the aldosterone receptor, with a shorter half-life and no active metabolite $[62,155,156]$. Eplerenone is mainly metabolized by CYP3A4 and is subjected to drug-drug interactions with inhibitors or strong affinity substrates of CYP3As (increased eplerenone AUC 2- to 5-fold) [157]. Spironolactone and eplerenone use can increase serum potassium, which may lead to clinically relevant hyperkaliemia [155]. In addition to standard therapy, a blockade of aldosterone by mineralocorticoid receptor antagonists has been associated with improved cardiovascular functions and survival rates among patients with severe heart failure [158,159].

\section{Renin Antagonist}

Aliskiren is an antagonist to renin and is indicated for the treatment of hypertension in adults and children six years of age and older [160]. Aliskiren has poor bioavailability (2.5\%) and most of the drug is metabolized by CYP3A4 [160]. In contrast to other antihypertensive agents and RAAS modulators, aliskiren, a direct inhibitor of renin, simultaneously reduces Ang I, Ang II, and plasma renin activity [161,162]. ACE inhibitors do not provide a full blockade of Ang II, and ARBs block the negative feedback of Ang II upon renin leading to increase in Ang II levels. Hence, both can lead to increases in plasma renin activity $[160,161]$.

\section{Effects of RAAS Modulators on ACE2 Expression}

Several modulators of the RAAS interact at different sites in the cascade and result in various effects on ACE2 levels (Figure 2). Table 1 summarizes major studies showing the effects of RAAS modulators on ACE2 mRNA, protein levels, and activity. Though a majority of these studies have been carried out in in vitro systems, they contribute significantly to our understanding of the role of RAAS modulators on ACE2 expression at a molecular level. Effects of these drugs on ACE2 depend on the system studied, the stage of disease progression, and the drug used. Altogether, case series and epidemiological and clinical observations of patients with SARS-CoV-2 have reported that older ages and presence of comorbidities, including cardiovascular disease, diabetes, and chronic hypertension, are associated with poor prognosis and a high rate of mortality [163]. Patients with these comorbidities are usually treated with RAAS modulators, including ACE inhibitors, ARBs, mineralocorticoid receptor antagonists, and renin antagonists (some restrictions in diabetic patients or treated with other anti-hypertensive drugs are identified in the monograph of the respective drugs). The impact of these drugs on ACE2 plasma levels or expression are still a matter of controversy, although recent studies tend to demonstrate that ACE2 plasma levels are not increased by RAAS modulators [96].

\section{RAAS Modulators and Pneumonia Risk}

A closer look at the association between the use of ACE inhibitors and the risk of pneumonia-related mortality has been the subject of several publications for more than 20 years [164]. Pleiotropic effects of ACE inhibitors on various regulatory systems could potentially be beneficial, but could also be considered potentially deleterious. For instance, silent aspiration is prevalent among elderly patients with an impaired cough reflex, a known predisposing factor for pneumonia [165,166]. It has been proposed that a cough induced by ACE inhibitors due to the block of substance P degradation could be beneficial $[167,168]$. Others have suggested that the anti-inflammatory properties of ACE inhibitors (decreased production of inflammatory molecules such as reactive oxygen intermediates, adhesion molecules, growth factors, chemokines, and cytokines), when used chronically, could prevent the development of lung fibrosis and improve the lung's ability to respond to additional insults, such as infections [169-173]. Some researchers argue that the ARBs share several of these properties (minus the cough reflex) and could also be beneficial in the case of lung infections [174].

Answers to some of these hypotheses have been provided in several clinical studies. At the beginning of the 2000s, a series of randomized controlled trials demonstrated that patients on ACE inhibitors had a decreased incidence of pneumonia [175-177]. Around the same time, other studies could 
not confirm such protective effects [178-180]. For instance, the study by Liappis et al. demonstrated that ACE inhibitor use was associated with decreased rates in survival (odds ratio of $2.1 ; 95 \%$ confidence interval of 1.1-4.3) [181]. In a follow-up study, Mortensen et al. suggested that the reason for such divergent results could be because ACE inhibitors may not be all the same [182]. Results obtained from 186 patients hospitalized with pneumonia undergoing treatment with an ACE inhibitor demonstrated that a 30-day mortality rate (9.2\%) was associated with the use of lipophilic ACE inhibitors (quinapril, fosinopril, ramipril), but not of hydrophilic ACE inhibitors (lisinopril, captopril, enalapril).

Mortensen et al. also proposed that patients with either community- or hospital-acquired pneumonia had favorable outcomes if treated with ACE inhibitors and HMG-CoA reductase inhibitors [183]. A large study conducted by Lui et al., in 10,990 cases of patients hospitalized for pneumonia, concluded that there was no association between the use or the cumulative dose of ACE inhibitors or ARBs and risk of pneumonia [184]. Another large study conducted in 215,225 patients concluded that there was an association between the use of ACE inhibitors and ARBs and a delay in the progression of pulmonary complications in vulnerable populations [185]. Finally, a meta-analysis performed by Caldeira et al. in 2012 looked at 37 studies demonstrating that ACE inhibitors were associated with a significantly reduced risk of pneumonia in comparison to control treatment and ARBs [186]. Compared to control treatments, both ACE inhibitors (7 studies) and ARBs (1 study) were associated with a decrease in pneumonia-related mortality, without differences in intervention. They concluded that the best evidence available pointed towards a putative protective role of ACE inhibitors, but not ARBs, in risk of pneumonia.

\section{Other Drug Classes and ACE2 Modulation: HMG-CoA Reductase Inhibitors}

As mentioned previously, Mortensen et al. demonstrated that patients with either community- or hospital-acquired pneumonia had favorable outcomes if treated with ACE inhibitors and HMG-CoA reductase inhibitors (statins) [183]. In an extensive review, Fedson presents new paradigms about the treatment of serious infection diseases, including Ebola, and how we should learn from the past [187]. He strongly advocates that use of drugs such as ACE inhibitors and statins would have a major impact on patient outcomes for those experiencing severe virus infections. In silico studies performed by Reiner et al., demonstrated that statins, especially pitavastatin, have a binding energy to SARs-CoV-2 main protease-a key coronavirus enzyme- that is even greater than that of protease or polymerase inhibitors [188]. Statins have been suggested to possess pleiotropic effects including inhibition of deleterious effects associated with RAAS overactivation. Modulation of ACE2 induced by statins is mostly described in animal experiments, cell experimental models and/or under disease situations [189-192]. Thus, the upregulation induced by statins might represent a normalization of ACE2 levels. Another pleiotropic effect of statins is the modulation of CD-147, which is another cell surface protein beside ACE2 that could interact with coronavirus entry [193-196]. In a viewpoint publication, Katsiki et al. presented elements in support of maintaining the use of statins in patients with COVID-19 due to their beneficial effects on inflammation, vascular, heart, and lung functions [197].

\section{Getting Answers to the Central Question}

Whether ACE inhibitor and/or ARB use is clearly beneficial, neutral, or deleterious in the context of COVID-19-induced pneumonia remains to be seen, and this represents a significant gap in the literature that some have described as a possible "double-edged sword" [198,199]. As mentioned previously, pharmacologic RAAS inhibition may upregulate ACE2 expression, which may amplify the virulence of SARS-CoV-2 within the pulmonary systems due to virus S-protein binding to ACE2 in order to gain entry into cells $[26,30,45,130]$. In this scenario, it is proposed that the use of ACE inhibitors and ARBs might predispose patients to a more severe SARS-CoV-2 infection [12]. In contrast, as explained above, mechanistic studies from related coronaviruses have shown that RAAS activation and resulting reduction in ACE2 expression plays an essential role in the pathogenesis of lung injury, acute respiratory distress syndrome, and fulminant myocarditis after SARS-CoV infection due to toxic 
overaccumulation of Ang II [72]. In this situation, using RAAS modulators could lead to elevated ACE2 expression and Ang-(1-7) levels, increasing their cardioprotective effects, which may be beneficial in protecting against infection.

Answer to these questions have started to be clearer as a recent communication by the World Health Organization (WHO) recognizes concerns that have been raised between the use of RAAS modulators and increased susceptibility to SARS-CoV-2 and the likelihood of severe COVID-19 illness [16]. A review of 11 observational studies ( 8 of which were conducted in China), led them to conclude "that there is low-certainty evidence that patients on long-term therapy with ACE inhibitors or ARBs are not at risk of poor outcomes from COVID-19". Furthermore, from the results of their recent observational study in Medicare and commercially insured populations, Khera et al. conclude that "the use of ACE inhibitors and ARBs was not associated with the risk of hospitalization or mortality among those infected with SARS-CoV-2" [17]. In addition, they suggest that the risk of hospitalization was lower in ACE inhibitor users. The meta-analysis conducted by Mackey et al. led them to conclude that "High-certainty evidence suggests that ACE inhibitor or ARB use is not associated with more severe COVID-19 disease, and moderate-certainty evidence suggest no association between use of these medications and positive SARS-CoV-2 test results among symptomatic patients. Whether these medications increase the risk for mild or asymptomatic disease or are beneficial in COVID-19 treatment remains uncertain" [18].

\section{Conclusions}

Until we have clear evidence, $\mathrm{WHO}$ and numerous professional organizations urged patients at risk of, or currently infected with, $\mathrm{HCoV}$ such as COVID-19 to continue their RAAS modulator therapy as prescribed $[15,16]$. Based on premises presented here, there are ongoing clinical trials across the world investigating the efficacy and safety of RAAS modulators in COVID-19 prevention and treatment (Table 2; a constant update of this information could be found at https://trhc.spprdi.com/covid19/). There is limited current evidence available in patients tested positive for SARS-CoV-2 of the benefit or harm of RAAS modulators. Well-designed prospective and retrospective observational studies, in addition to randomized controlled clinical trials, will be essential for creating a guidance for use or non-use of RAAS modulators in SARS-CoV-2 infection [200]. Results from COVID-19 clinical studies may provide key insights into the differences between classes of drugs (ACE inhibitors, ARBs, mineralocorticoid receptor antagonists, statins) or the differences among drugs within the same drug class (lipophilicity, tissue vs. serum ACE inhibition) or whether outcomes from SARS-CoV-2 pneumonia in patients treated with RAAS modulators differ from other types of virus-induced pneumonia.

In conclusion, maintaining high levels of tissue ACE2 activity appears to be beneficial for preventing exacerbated inflammatory response during COVID-19 infection, while increased plasma ACE2 levels are associated with cardiovascular complications [96]. Both sex- and racial-related genetic variants are observed in ACE2; some variants may also confer resistance [109].

The close relationship between the mechanism of SARS-CoV-2 entry into the cells, ACE2, and the significant number of patients affected by COVID-19 with comorbidities requiring use of RAAS modulators, presents a conundrum that can only be solved by focused clinical studies. Though the current level of evidence is not strong enough to build clinical guidelines, it provides a clear direction and roadmap for future investigations. 
Table 1. Clinical and experimental studies investigating impacts of several cardiopulmonary diseases and RAAS modulators on ACE2 expression and activity.

\begin{tabular}{|c|c|c|c|c|}
\hline Drug Class & System Studied & Condition & Drugs & Impact on ACE2 \\
\hline \multirow{9}{*}{ ACE-I } & In vitro in $\mathrm{CHO}$ cells [75] & \multirow{3}{*}{ Healthy } & Captopril, Enalapril, Lisinopril & No change in ACE2 activity \\
\hline & In vivo in rat renal cells [201] & & Lisinopril, low sodium diet, or both & Combination lisinopril and low sodium diet decreased ACE2 $\mathrm{mRNA}$ \\
\hline & In vivo in rat cardiac (LV) cells [202] & & Lisinopril & Increase in ACE2 mRNA \\
\hline & In vivo in rat cardiac cells [73] & \multirow{2}{*}{ MI } & Ramipril & No effect on ACE2 mRNA or activity \\
\hline & In vivo in rat cardiac (LV) and plasma cells [203] & & Enalapril & Prevention of decrease in ACE2 $\mathrm{mRNA}$ and activity 8 weeks post-MI \\
\hline & $\begin{array}{l}\text { In vivo in rat pulmonary tissue and } \\
\text { in vitro in rat PMVECs [204] }\end{array}$ & ALI & Captopril & Increase in ACE2 protein level \\
\hline & In vivo in human intestinal cells [205] & Likely HTN & Any ACE-Is & Increase in intestinal ACE2 mRNA \\
\hline & In vivo in human urine [206] & HTN & Enalapril & No change in ACE2 protein level in urine \\
\hline & In vivo in human heart $(\mathrm{LV})$ tissue [207] & $\mathrm{HF}$ & Any ACE-Is & $\begin{array}{l}\text { ACE and ACE2 immunoreactivity were quantitatively increased in cardiac tissue from failing hearts }(n=5) \\
\text { due to ischemic heart disease compared to the non-ischemic heart controls }(n=3)\end{array}$ \\
\hline \multirow{11}{*}{ ARB } & In vivo in rat cardiac (LV) cells [208] & Healthy & \multirow{2}{*}{ Losartan } & Increase in ACE2 mRNA and activity \\
\hline & In vivo in rat cardiac (LV)/ renal cells [209] & \multirow{3}{*}{ HTN } & & Potentiation of renal upregulation of ACE2 $\mathrm{mRNA}$ \\
\hline & In vivo in rat aorta/carotid artery cells [210] & & Olmesartan & Increase in ACE2 mRNA and activity \\
\hline & In vivo in rat cardiac (aorta) cells [211] & & Telmisartan & Decrease in ACE2 activity \\
\hline & \multirow{3}{*}{ In vivo in rat cardiac cells } & \multirow[b]{2}{*}{ MI } & Losartan, Olmesartan [212] & Increase in ACE2 $\mathrm{mRNA}$ \\
\hline & & & Valsartan [213] & No effect on ACE2 mRNA or activity \\
\hline & & $\mathrm{HF}$ & Eprosartan [214] & Increase in ACE2 activity \\
\hline & In vivo in rat BALF [215] & ARDS & Losartan & Increase in ACE2 activity \\
\hline & In vitro in human UASMCs [211] & Healthy & Telmisartan & Decrease in ACE2 activity \\
\hline & In vivo in human intestinal cells [205] & Likely HTN & Any ARBs & No changes in intestinal ACE2 mRNA \\
\hline & In vivo in human urine [206] & HTN & $\begin{array}{l}\text { Candesartan, Losartan } \\
\text { Olmesartan, Telmisartan, } \\
\text { Valsartan }\end{array}$ & ACE2 protein level was increased after treatment ( $>1$ year) [Olmesartan only] \\
\hline \multirow{2}{*}{ ACE-I + ARB } & In vivo in rat cardiac (LV) cells [208] & Healthy & Lisinopril + Losartan & Increase in ACE2 activity, but decrease in ACE2 $\mathrm{mRNA}$ \\
\hline & In vivo in rat cardiac cells [213] & MI & Ramipril + Valsartan & No effect on ACE2 mRNA or protein levels \\
\hline \multirow{4}{*}{ MRA } & In vivo in mice peritoneal macrophages/ cardiac cells [216] & Healthy & Eplerenone & Increase in ACE2 mRNA and activity \\
\hline & In vivo in rat cardiac cells [214] & \multirow{3}{*}{$\mathrm{HF}$} & \multirow{2}{*}{ Spironolactone } & Trending increase in ACE2 activity $(p=0.067)$ \\
\hline & In vivo in human monocyte-derived macrophages [216] & & & Increase in ACE2 mRNA and activity \\
\hline & In vivo in human plasma [217] & & Any MRAs & MRAs were found to independently associate with plasma SACE2 plasma activity \\
\hline RI & In vivo in rat renal cells [218] & DN & Aliskiren & Decrease in ACE2 activity \\
\hline
\end{tabular}


Table 1. Cont

\begin{tabular}{|c|c|c|c|c|c|c|c|c|c|}
\hline Drug Class & System Studied & Condition & Drugs & \multicolumn{6}{|c|}{ Impact on ACE2 } \\
\hline \multirow{8}{*}{ None } & In vivo in mice pulmonary cells and in vitro in Vero $\mathrm{E} 6 \mathrm{cel}$ & \multirow{4}{*}{ SARS-CoV LRTI } & & \multicolumn{6}{|c|}{$\begin{array}{l}\text { SARS-CoV Spike protein binding to ACE2 in mice lungs in vivo or in cell lines resulted in reduced surface } \\
\text { ACE2 protein levels. }\end{array}$} \\
\hline & In vitro in human A549 alveolar epithelial cells [72] & & & \multicolumn{6}{|c|}{ SARS-CoV Spike protein binding to ACE2 in human AECs resulted in reduced surface ACE2 protein level. } \\
\hline & In vivo in mice cardiac cells [219] & & & \multicolumn{6}{|c|}{ Decrease in ACE2 mRNA and activity } \\
\hline & In vivo in human cardiac cells [219] & & & \multicolumn{6}{|c|}{ Decrease in ACE2 protein level } \\
\hline & In vivo in bronchoalveolar lavage fluid of rats [215] & ARDS & & In bronch & $\begin{array}{l}\text { Dalveolar lavage } \\
\text { activity was re }\end{array}$ & $\begin{array}{ll}\text { from LPS } \\
\text { ( (30-fold) }\end{array}$ & $\begin{array}{l}\text { sed rats, ACE } \\
\text { ntrols, decrea }\end{array}$ & $\begin{array}{l}\text { tivity was augmented (9-1 } \\
\text { ng the ACE/ACE2 activity }\end{array}$ & $\begin{array}{l}\text { old) while ACE2 } \\
\text { ratio }\end{array}$ \\
\hline & In vivo in rat cardiac (LV)/ plasma cells [203] & MI & & ACE2 $\mathrm{m}$ & RNA and activit & $\begin{array}{r}\text { e increase } \\
\text { low }\end{array}$ & $\begin{array}{l}\text { veek } 1 \text { post } \mathrm{M} \\
\text { in controls at } \mathrm{v}\end{array}$ & $\begin{array}{l}\text { ompared to controls, hou } \\
\text { ek } 8 .\end{array}$ & ever, they were \\
\hline & In vivo in mice cardiac cells [220] & $\mathrm{HF}$ & \multirow[b]{2}{*}{ Ang-(1-7) } & $\begin{array}{r}\text { Advers } \\
\text { patl }\end{array}$ & $\begin{array}{l}\text { e remodeling in } \\
\text { hological effects }\end{array}$ & $\begin{array}{l}\text { ure-overlc } \\
\text { g II on ca: }\end{array}$ & $\begin{array}{l}\text { ACE2-deficie } \\
\text { cells that can } b\end{array}$ & $\begin{array}{l}\text { hearts is facilitated by a } \\
\text { successfully inhibited by }\end{array}$ & $\begin{array}{l}\text { ombination of } \\
\text { Ang-(1-7). }\end{array}$ \\
\hline & In vivo in bronchoalveolar lavage fluid of rats [215] & ARDS & & In broncl & oalveolar lavage & $\begin{array}{l}\text { from LP } \\
\text { activity }\end{array}$ & $\begin{array}{l}\text { osed rats, the } \\
\text { ared to the pla }\end{array}$ & $\begin{array}{l}\text { posure to } \text { Ang-(1-7) incr } \\
\text { poo group }\end{array}$ & ased the ACE2 \\
\hline \multicolumn{10}{|c|}{$\begin{array}{l}\text { ACE-I: angiotensin-converting enzyme inhibitor; ALI: acute lung injury; Ang-(1-7): Angiotensin-(1-7); Ang II: angiotensin II; ARB: angiotensin-receptor blockers; ARDS: acute respiratory } \\
\text { distress syndrome; CHO: Chinese hamster ovary; DN: diabetic nephropathy; EMC: encephalomyocarditis; HF: heart failure; HTN: hypertension; IHD: ischemic heart disease; LPS: } \\
\text { lipopolysaccharide; LRTI: lower respiratory tract infection; LV: left ventricle; MI: myocardial infarction; MRA: mineralocorticoid receptor antagonist; mRNA: messenger RNA; NA: } \\
\text { not applicable; PMVECs: pulmonary microvascular endothelial cells; RAAS: renin angiotensin-aldosterone system; rhACE2: recombinant human angiotensin-converting enzyme 2; RI: } \\
\text { renin inhibitor; RSV: respiratory syncytial virus; SARS-CoV: severe acute respiratory syndrome coronavirus; UASMCs: umbilical artery smooth muscle cells. The yellow and blue colors } \\
\text { represent experiments conducted in animals or human, respectively. }\end{array}$} \\
\hline Drug Class & Treatment & Type of Study & COVID-19 Status & Setting & Severity & Phase & Country & $\begin{array}{l}\text { Trial Status (Expected } \\
\mathrm{N})\end{array}$ & Trial ID \\
\hline \multirow{3}{*}{ ACE-I } & Ramipril vs. placebo & $\begin{array}{l}\text { Triple-blind, placebo-controlled; } \\
\text { efficacy }\end{array}$ & Confirmed & HOSP or ED & Non-severe & 2 & us & Not yet recruiting $(560)$ & NCT04366050 \\
\hline & Captopril vs. SOC & Open label; efficacy & Confirmed & HOSP & ARDS & 2 & France & Not yet recruiting (230) & NCT04355429 \\
\hline & Captopril or enalapril vs. CQ & Open label; efficacy & Confirmed & Unspecified & Unspecified & 3 & Egypt & Not yet recruiting (60) & NCT04345406 \\
\hline \multirow{7}{*}{ ARB } & Valsartan vs. placebo & $\begin{array}{c}\text { Quadruple-blind, } \\
\text { placebo-controlled; efficacy }\end{array}$ & Confirmed & HOSP & Mixed & 4 & Netherlands & Recruiting (651) & NCT04335786 \\
\hline & $\begin{array}{l}\text { Chloroquine/Hydroxychloroquine vs. LPV/r vs. SOC } \\
\text { vs. Rivaroxaban vs. TP vs. Candesartan vs. non-RAS } \\
\text { AHT vs. Clazakizumab vs. Placebo }\end{array}$ & $\begin{array}{l}\text { Open label; active-controlled; } \\
\text { efficacy }\end{array}$ & Confirmed & $\begin{array}{l}\text { Healthy, } \\
\text { Outpatient, HOSP }\end{array}$ & Mixed & $2 / 3$ & Austria & Recruiting (500) & NCT04351724 \\
\hline & Telmisartan vs. Placebo & $\begin{array}{l}\text { Triple-blind, placebo-controlled; } \\
\text { efficacy and safety }\end{array}$ & Confirmed & Outpatient & Non-severe & 2 & us & Not yet recruiting $(40)$ & NCT04360551 \\
\hline & SOC vs Telmisartan $+\mathrm{SOC}$ & Open label; efficacy & Confirmed & Unspecified & Unspecified & 2 & Argentina & Recruiting (400) & NCT04355936 \\
\hline & $\begin{array}{l}\text { Hydroxychloroquine vs. Azithromycin vs. Telmisartan } \\
\text { vs. SOC }\end{array}$ & Open label; efficacy & Confirmed & HOSP & Mixed & 3 & France & $\begin{array}{l}\text { Not yet recruiting } \\
(1600)\end{array}$ & NCT04359953 \\
\hline & $\begin{array}{l}\text { Vitamins vs. Hydroxychloroquine vs. Imatinib vs. } \\
\text { Favipiravir vs. Telmisartan }\end{array}$ & $\begin{array}{c}\text { Open label, multi-stage, } \\
\text { superiority; efficacy and safety }\end{array}$ & Confirmed & Outpatient & Mild & 3 & France & Recruiting (1057) & NCT04356495 \\
\hline & Losartan & Open label; safety & Confirmed & ICU or HOSP & ARDS & 1 & US & Recruiting (50) & NCT04335123 \\
\hline
\end{tabular}


Table 2. Cont.

\begin{tabular}{|c|c|c|c|c|c|c|c|c|c|}
\hline Drug Class & Treatment & Type of Study & COVID-19 Status & Setting & Severity & Phase & Country & $\begin{array}{l}\text { Trial Status (Expected } \\
\text { N) }\end{array}$ & Trial ID \\
\hline & Losartan vs. Placebo & $\begin{array}{c}\text { Quadruple-blind, } \\
\text { placebo-controlled; efficacy }\end{array}$ & Confirmed & Outpatient & Non-severe & 2 & US & Recruiting (580) & NCT04311177 \\
\hline & Losartan vs. Placebo & $\begin{array}{l}\text { Quadruple-blind, placebo- } \\
\text { controlled; efficacy }\end{array}$ & $\begin{array}{l}\text { Confirmed or } \\
\text { Suspected }\end{array}$ & HOSP & ARDS & 2 & US & Recruiting (200) & NCT04312009 \\
\hline & SOC vs. Losartan + SOC & Open label; efficacy & Confirmed & HOSP & $\begin{array}{l}\text { Mild/ } \\
\text { Moderate }\end{array}$ & 4 & US & Recruiting (200) & NCT04340557 \\
\hline & Losartan vs. Amlodipine & Open label; efficacy and safety & Confirmed & HOSP & Non-severe & 3 & Iran & Recruiting (100) & $\begin{array}{l}\text { IRCT201808020 } \\
40678 \mathrm{~N} 4\end{array}$ \\
\hline & $\begin{array}{l}\text { SOC vs. ASA vs. Losartan vs. Simvastatin vs. ASA + } \\
\text { losartan vs. ASA + Simvastatin vs. Losartan + } \\
\text { Simvastatin vs. ASA + Losartan + Simvastatin }\end{array}$ & Open label, factorial; efficacy & $\begin{array}{l}\text { Confirmed or } \\
\text { Suspected }\end{array}$ & HOSP & Mixed & 3 & $\begin{array}{l}\text { Nigeria, } \\
\text { Pakistan }\end{array}$ & $\begin{array}{l}\text { Not yet recruiting } \\
(10,000)\end{array}$ & NCT04343001 \\
\hline & $\begin{array}{l}\text { SOC + LPV/r vs. SOC + Hydroxychloroquine vs. SOC } \\
\text { + Losartan vs. SOC + Placebo }\end{array}$ & $\begin{array}{l}\text { Quadruple-blind, } \\
\text { placebo-controlled; efficacy }\end{array}$ & Confirmed & HOSP & Mixed & $2 / 3$ & US & Recruiting (4000) & NCT04328012 \\
\hline & $\begin{array}{l}\text { Hydroxychloroquine + Azithromycin vs. } \\
\text { Hydroxychloroquine + Doxycycline vs. } \\
\text { Hydroxychloroquine + Clindamycin vs. } \\
\text { Hydroxychloroquine + Clindamycin + Primaquine low } \\
\text { dose vs Hydroxychloroquine + Clindamycin+ } \\
\text { Primaquine high dose vs. Remdesivir vs. Tocilizumab } \\
\text { vs. Methylprednisolone vs. Interferon- } \alpha 2 \text { vs. } \\
\text { Losartan vs. Plasma } \\
\end{array}$ & Single-blind, factorial; efficacy & Confirmed & HOSP & Unspecified & $2 / 3$ & US & $\begin{array}{l}\text { Enrolling by invitation } \\
\qquad(500)\end{array}$ & NCT04349410 \\
\hline & ARBs vs. SOC & $\begin{array}{c}\text { Single-blinded; parallel } \\
\text { assignment; safety and efficacy }\end{array}$ & Confirmed & HOSP & Unspecified & 4 & Australia & Recruiting (605) & NCT04394117 \\
\hline & ARBs vs. SOC & $\begin{array}{l}\text { Prospective observational; safety, } \\
\text { efficacy, ACE2 activity }\end{array}$ & Confirmed & HOSP & $\begin{array}{l}\text { COVID+ } \\
\text { ARDS }\end{array}$ & NA & France & Recruiting (100) & NCT04337190 \\
\hline & Chloroquine + Losartan vs. Chloroquine & $\begin{array}{l}\text { Randomized, double blinded; } \\
\text { safety and efficacy }\end{array}$ & Confirmed & HOSP & Unspecified & 2 & Mexico & Recruiting (20) & NCT04428268 \\
\hline \multirow{9}{*}{ ACE-I or ARB } & $\begin{array}{l}\text { D/C ACE-I/ARB and switch to CCB or TZD vs continue } \\
\text { ACE-I/ARB }\end{array}$ & Open label; prevention & COVID-19 naive & Healthy & NA & 4 & Ireland & Recruiting (2414) & NCT04330300 \\
\hline & $\mathrm{D} / \mathrm{C}$ vs continue ACE-I/ARB & Single-blind; efficacy & $\begin{array}{l}\text { Confirmed or } \\
\text { Suspected }\end{array}$ & HOSP & Mixed & NA & US & $\begin{array}{l}\text { Enrolling by invitation } \\
\text { (152) }\end{array}$ & NCT04338009 \\
\hline & $\mathrm{D} / \mathrm{C}$ vs continue ACE-I/ARB & Single-blind; efficacy & Confirmed & HOSP & Mild & 4 & $\begin{array}{l}\text { Austria, } \\
\text { Germany }\end{array}$ & Recruiting (208) & NCT04353596 \\
\hline & $\mathrm{D} / \mathrm{C}$ vs continue $\mathrm{ACE}-\mathrm{I} / \mathrm{ARB}$ & Single-blind; efficacy & Confirmed & HOSP & Mixed & NA & Denmark & Recruiting (215) & NCT04351581 \\
\hline & $\mathrm{D} / \mathrm{C}$ vs continue $\mathrm{ACE}-\mathrm{I} / \mathrm{ARB}$ & Open label; efficacy & Confirmed & HOSP & Mild & NA & Brazil & Recruiting (500) & NCT04364893 \\
\hline & D/C vs continue ACE-I/ARB & Open label; efficacy and safety & Confirmed & HOSP & Mild & 3 & France & Recruiting (554) & NCT04329195 \\
\hline & Use vs no use of ACE-I/ARB & $\begin{array}{l}\text { Prospective observational; } \\
\text { prognosis }\end{array}$ & Confirmed & HOSP & Unspecified & NA & Saudi Arabia & Recruiting (226) & NCT04357535 \\
\hline & ACE-I/ARB/ direct renin inhibitors (DRi) & $\begin{array}{c}\text { Prospective observational; } \\
\text { prognosis and efficacy } \\
\text { (hypertension) }\end{array}$ & Confirmed & Private practice & Unspecified & NA & Ukraine & Recruiting (10) & NCT04364984 \\
\hline & ARB/ACE-I vs anti-malarial drugs & $\begin{array}{l}\text { Prospective, observational; } \\
\text { prognosis }\end{array}$ & Confirmed & HOSP & Unspecified & NA & France & $\begin{array}{c}\text { Not yet recruiting } \\
(6,000,000)\end{array}$ & NCT04356417 \\
\hline
\end{tabular}


Table 2. Cont.

\begin{tabular}{|c|c|c|c|c|c|c|c|c|c|}
\hline Drug Class & Treatment & Type of Study & COVID-19 Status & Setting & Severity & Phase & Country & $\begin{array}{c}\text { Trial Status (Expected } \\
\text { N) }\end{array}$ & Trial ID \\
\hline & ARB/ ACE-I/ influenza vaccine vs. SOC & $\begin{array}{l}\text { Prospective, observational; } \\
\text { efficacy }\end{array}$ & Confirmed & HOSP & Unspecified & NA & Spain & Recruiting (2547) & NCT04367883 \\
\hline & ACE-I/ARB + SOC vs. SOC & $\begin{array}{l}\text { Retrospective, case-control; } \\
\text { severity and mortality of/ from } \\
\text { COVID }\end{array}$ & Confirmed & Unspecified & $\begin{array}{c}\text { ARDS vs. } \\
\text { non-ARDS } \\
\text { COVID }\end{array}$ & NA & Italy & $\begin{array}{c}\text { Not yet recruiting } \\
(5000)\end{array}$ & NCT04318418 \\
\hline & ACE-I/ARB +SOC vs. SOC & $\begin{array}{c}\text { Retrospective, case-control; } \\
\text { safety }\end{array}$ & Confirmed & HOSP & Unspecified & NA & France & Not yet recruiting $(700)$ & NCT04374695 \\
\hline & ACE-I/ARB + SOC vs. SOC & $\begin{array}{l}\text { Open-label, case control; } \\
\text { prognosis }\end{array}$ & Confirmed & HOSP & Any severity & NA & Italy & Recruiting (2000) & NCT04331574 \\
\hline \multirow{2}{*}{ MRA } & Spironolactone vs. Placebo & $\begin{array}{l}\text { Triple-blind, placebo-controlled; } \\
\text { efficacy }\end{array}$ & Confirmed & ICU & ARDS & 4 & Turkey & Not yet recruiting $(60)$ & NCT04345887 \\
\hline & Bromohexine + spironolactone vs. standard therapy & $\begin{array}{l}\text { Single-blind, parallel assignment; } \\
\text { efficacy }\end{array}$ & Confirmed & HOSP & $\begin{array}{l}\text { Mild to } \\
\text { moderate }\end{array}$ & 3 & Russia & Recruiting & NCT04424134 \\
\hline \multirow{2}{*}{$\begin{array}{l}\text { MAS receptor } \\
\text { agonist }\end{array}$} & Angiotensin-(1-7) vs Placebo & $\begin{array}{l}\text { Triple-blind, placebo-controlled; } \\
\text { efficacy and safety }\end{array}$ & $\begin{array}{l}\text { Confirmed or } \\
\text { Suspected }\end{array}$ & ICU & ARDS & $2 / 3$ & Belgium & Not yet recruiting (60) & NCT04332666 \\
\hline & Plasma derived Angiotensin-(1-7) vs. SOC & Open label; efficacy & Confirmed & HOSP & NA & NA & Turkey & Recruiting & NCT04375124 \\
\hline $\begin{array}{l}\text { Recombinant } \\
\text { ACE-2 }\end{array}$ & Recombinant human ACE-2 (APN01) vs. placebo & $\begin{array}{c}\text { Double-blind, } \\
\text { placebo-controlled; efficacy }\end{array}$ & Confirmed & HOSP & Mixed & 2 & $\begin{array}{c}\text { Austria, } \\
\text { Denmark, } \\
\text { Germany }\end{array}$ & Recruiting (200) & NCT04335136 \\
\hline
\end{tabular}

Key: ACE-I: angiotensin-converting enzyme inhibitor; AHT: antihypertensive; ARB: angiotensin II receptor blocker; ARDS: acute respiratory distress syndrome; ASA: acetylsalicylic acid BCC: calcium channel blockers; D/C: discontinuation; ED: emergency department; HOSP: hospitalized; HTN: hypertension; LPV/r: lopinavir/ritonavir; ICU: intensive care unit; MRA: mineralocorticoid receptor antagonist; NA: not applicable; RAS: renin angiotensin system; SOC: standard of care; TP: thromboprophylaxis; TZD: thiazolidinedione. NCTXXXXXXXX refers to registry number at the NIH ClinicalTrials.gov website. IRCT201808020 40678N4 refers to registry number at the Iranian Registry of Clinical Trials. An update of the information listed in this table can be found at https://trhc.spprdi.com/covid19/. * Excluded the following types of studies: retrospective case-control, prospective cohort with previous ARB use, and studies in which RAAS modulator use was not a primary focus. Table was updated on 6/23/20. 
Author Contributions: Conceptualization, V.M. and J.T.; writing—original draft preparation, V.M., M.D., M.A., S.B.A.R., P.D., and J.T.; writing-review and editing, V.M., J.T., and P.D.; visualization, M.D. and M.A.; supervision, V.M. and J.T.; All authors have read and agreed to the published version of the manuscript.

Funding: This research received no external funding.

Acknowledgments: The authors recognize the contribution of Ernesto Lucio for his design of the included figures. The authors also want to thank Dana Filippoli for her comprehensive review and comments on the content of this paper.

Conflicts of Interest: All authors declare no conflict of interest.

\section{References}

1. European Center for Disease Prevention and Control. Cluster of Pneumonia Cases Caused by a Novel Coronavirus, Wuhan, China. Available online: http://wjw.wuhan.gov.cn/front/web/showDetail/ 2019123108989 (accessed on 5 June 2020).

2. Zhou, P.; Yang, X.-L.; Wang, X.-G.; Hu, B.; Zhang, L.; Zhang, W.; Si, H.-R.; Zhu, Y.; Li, B.; Huang, C.-L.; et al. A pneumonia outbreak associated with a new coronavirus of probable bat origin. Nature 2020, 579, 270-273. [CrossRef] [PubMed]

3. Zhu, N.; Zhang, D.; Wang, W.; Li, X.; Yang, B.; Song, J.; Zhao, X.; Huang, B.; Shi, W.; Lu, R.; et al. A novel coronavirus from patients with pneumonia in China, 2019. N. Engl. J. Med. 2020, 382, 727-733. [CrossRef] [PubMed]

4. World Health Organization. Novel Coronavirus-China. Available online: https:/www.who.int/csr/don/12january-2020-novel-coronavirus-china/en/ (accessed on 5 June 2020).

5. World Health Organization. Coronavirus Disease (COVID-19) Pandemic. Available online: https://www. who.int/emergencies/diseases/novel-coronavirus-2019 (accessed on 5 June 2020).

6. Johns Hopkins University and Medicine. COVID-19 Dashboard by the Center for Systems Science and Engineering (CSSE) at Johns Hopkins University and Medicine. Available online: https://coronavirus.jhu. edu/map.html (accessed on 24 June 2020).

7. Huang, C.; Wang, Y.; Li, X.; Ren, L.; Zhao, J.; Hu, Y.; Zhang, L.; Fan, G.; Xu, J.; Gu, X.; et al. Clinical features of patients infected with 2019 novel coronavirus in Wuhan, China. Lancet 2020, 395, 497-506. [CrossRef]

8. Guan, W.-J.; Ni, Z.-Y.; Hu, Y.; Liang, W.-H.; Ou, C.-Q.; He, J.-X.; Liu, L.; Shan, H.; Lei, C.-L.; Hui, D.S.; et al. Clinical characteristics of coronavirus disease 2019 in China. N. Engl. J. Med. 2020, 382, 1708-1720. [CrossRef]

9. Wu, C.; Chen, X.; Cai, Y.; Xia, J.; Zhou, X.; Xu, S.; Huang, H.; Zhang, L.; Zhou, X.; Du, C.; et al. Risk factors associated with acute respiratory distress syndrome and death in patients with coronavirus disease 2019 Pneumonia in Wuhan, China. JAMA Intern. Med. 2020. [CrossRef]

10. Zhang, J.-J.; Dong, X.; Cao, Y.-Y.; Yuan, Y.-D.; Yang, Y.-B.; Yan, Y.-Q.; Akdis, C.A.; Gao, Y.-D. Clinical characteristics of 140 patients infected with SARS-CoV-2 in Wuhan, China. Allergy 2020. [CrossRef]

11. Zhou, F.; Yu, T.; Du, R.; Fan, G.; Liu, Y.; Liu, Z.; Xiang, J.; Wang, Y.; Song, B.; Gu, X.; et al. Clinical course and risk factors for mortality of adult inpatients with COVID-19 in Wuhan, China: A retrospective cohort study. Lancet 2020, 395, 1054-1062. [CrossRef]

12. Fang, L.; Karakiulakis, G.; Roth, M. Are patients with hypertension and diabetes mellitus at increased risk for COVID-19 infection? Lancet Respir. Med. 2020, 8, e21. [CrossRef]

13. Esler, M.; Esler, D. Can angiotensin receptor-blocking drugs perhaps be harmful in the COVID-19 pandemic? J. Hypertens. 2020, 38, 781-782. [CrossRef]

14. Watkins, J. Preventing a covid-19 pandemic. BMJ 2020, 368, m810. [CrossRef] [PubMed]

15. Kreutz, R.; AlGharably, E.A.E.-H.; Azizi, M.; Dobrowolski, P.; Guzik, T.; Januszewicz, A.; Persu, A.; Prejbisz, A.; Riemer, T.G.; Wang, J.-G.; et al. Hypertension, the renin-angiotensin system, and the risk of lower respiratory tract infections and lung injury: Implications for COVID-19. Cardiovasc. Res. 2020. [CrossRef] [PubMed]

16. World Health Organization. COVID-19 and the Use of Angiotensin-Converting Enzyme Inhibitors and Receptor Blockers. Available online: https:/www.who.int/news-room/commentaries/detail/covid-19-andthe-use-of-angiotensin-converting-enzyme-inhibitors-and-receptor-blockers (accessed on 5 June 2020).

17. Khera, R.; Clark, C.; Lu, Y.; Guo, Y.; Ren, S.; Truax, B.; Spatz, E.S.; Murugiah, K.; Lin, Z.; Omer, S.B.; et al. Association of angiotensin-converting enzyme inhibitors and angiotensin receptor blockers with the risk of hospitalization and death in hypertensive patients with coronavirus disease-19. medRxiv 2020. [CrossRef] 
18. Mackey, K.; King, V.J.; Gurley, S.; Kiefer, M.; Liederbauer, E.; Vela, K.; Sonnen, P.; Kansagara, D. Risks and impact of angiotensin-converting enzyme inhibitors or angiotensin-receptor blockers on sars-CoV-2 infection in adults. Ann. Int. Med. 2020. [CrossRef] [PubMed]

19. Dolinski, D.; Dolinska, B.; Zmaczynska-Witek, B.; Banach, M.; Kulesza, W. Unrealistic optimism in the time of coronavirus pandemic: May it help to kill, if so-Whom: Disease or the person? J. Clin. Med. 2020, 9, 1464. [CrossRef] [PubMed]

20. Bingham, J.M.; Arlington, L.; Madhat, F.; Michaud, V.; Turgeon, J. Adherence takes a hit during pandemic. Pharm. Times 2020. In press.

21. Lu, G.; Liu, D. SARS-like virus in the Middle East: A truly bat-related coronavirus causing human diseases. Protein Cell 2012, 3, 803-805. [CrossRef]

22. Enjuanes, L.; Almazán, F.; Sola, I.; Zuñiga, S. Biochemical Aspects of Coronavirus Replication and Virus-Host Interaction. Annu. Rev. Microbiol. 2006, 60, 211-230. [CrossRef] [PubMed]

23. Perlman, S.; Netland, J. Coronaviruses post-SARS: Update on replication and pathogenesis. Nat. Rev. Genet. 2009, 7, 439-450. [CrossRef] [PubMed]

24. Su, S.; Wong, G.; Shi, W.; Liu, J.; Lai, A.C.; Zhou, J.; Liu, W.; Bi, Y.; Gao, G.F. Epidemiology, genetic recombination, and pathogenesis of coronaviruses. Trends Microbiol. 2016, 24, 490-502. [CrossRef] [PubMed]

25. World Health Organization. Human Coronavirus Types. Available online: https://www.cdc.gov/coronavirus/ types.html (accessed on 25 June 2020).

26. Li, F. Structure, function, and evolution of coronavirus spike proteins. Annu. Rev. Virol. 2016, 3, $237-261$. [CrossRef] [PubMed]

27. Wevers, B.A.; Van Der Hoek, L. Recently discovered human coronaviruses. Clin. Lab. Med. 2009, 29, 715-724. [CrossRef] [PubMed]

28. Choi, E.H.; Lee, H.-J.; Kim, S.J.; Eun, B.W.; Kim, N.H.; A Lee, J.; Lee, J.H.; Song, E.K.; Kim, S.H.; Park, S.H.K.J.Y.; et al. The association of newly identified respiratory viruses with lower respiratory tract infections in Korean children, 2000-2005. Clin. Infect. Dis. 2006, 43, 585-592. [CrossRef] [PubMed]

29. Zhu, Y.; Li, C.; Chen, L.; Xu, B.; Zhou, Y.; Cao, L.; Shang, Y.; Fu, Z.; Chen, A.; Deng, L.; et al. A novel human coronavirus OC43 genotype detected in mainland China. Emerg. Microbes Infect. 2018, 7, 1-4. [CrossRef]

30. Walls, A.C.; Park, Y.-J.; Tortorici, M.A.; Wall, A.; McGuire, A.T.; Veesler, D. Structure, function, and antigenicity of the SARS-CoV-2 spike glycoprotein. Cell 2020, 181, 281-292.e6. [CrossRef] [PubMed]

31. Cui, J.; Li, F.; Shi, Z. Origin and evolution of pathogenic coronaviruses. Nat. Rev. Genet. 2018, 17, 181-192. [CrossRef]

32. Fehr, A.R.; Perlman, S. Coronaviruses: An overview of their replication and pathogenesis. Recent Results Cancer Res. 2015, 1282, 1-23. [CrossRef]

33. Shereen, M.A.; Khan, S.; Kazmi, A.; Bashir, N.; Siddique, R. COVID-19 infection: Origin, transmission, and characteristics of human coronaviruses. J. Adv. Res. 2020, 24, 91-98. [CrossRef]

34. Lu, G.; Wang, Q.; Gao, G.F. Bat-to-human: Spike features determining 'host jump' of coronaviruses SARS-CoV, MERS-CoV, and beyond. Trends Microbiol. 2015, 23, 468-478. [CrossRef]

35. Belouzard, S.; Millet, J.K.; Licitra, B.N.; Whittaker, G.R. Mechanisms of coronavirus cell entry mediated by the viral spike protein. Viruses 2012, 4, 1011-1033. [CrossRef]

36. Heald-Sargent, T.; Gallagher, T. Ready, set, fuse! The coronavirus spike protein and acquisition of fusion competence. Viruses 2012, 4, 557-580. [CrossRef]

37. Millet, J.K.; Whittaker, G.R. Host cell proteases: Critical determinants of coronavirus tropism and pathogenesis. Virus Res. 2014, 202, 120-134. [CrossRef] [PubMed]

38. Glowacka, I.; Bertram, S.; Müller, M.A.; Allen, P.; Soilleux, E.; Pfefferle, S.; Steffen, I.; Tsegaye, T.S.; He, Y.; Gnirss, K.; et al. Evidence that TMPRSS2 activates the severe acute respiratory syndrome coronavirus spike protein for membrane fusion and reduces viral control by the humoral immune response. J. Virol. 2011, 85, 4122-4134. [CrossRef] [PubMed]

39. Bertram, S.; Glowacka, I.; Müller, M.A.; Lavender, H.; Gnirss, K.; Nehlmeier, I.; Niemeyer, D.; He, Y.; Simmons, G.; Drosten, C.; et al. Cleavage and activation of the severe acute respiratory syndrome coronavirus spike protein by human airway trypsin-like protease. J. Virol. 2011, 85, 13363-13372. [CrossRef] [PubMed]

40. Shulla, A.; Heald-Sargent, T.; Subramanya, G.; Zhao, J.; Perlman, S.; Gallagher, T. A Transmembrane serine protease is linked to the severe acute respiratory syndrome coronavirus receptor and activates virus entry. J. Virol. 2010, 85, 873-882. [CrossRef] [PubMed] 
41. Kam, Y.-W.; Okumura, Y.; Kido, H.; Ng, L.F.P.; Bruzzone, R.; Altmeyer, R. Cleavage of the SARS coronavirus spike glycoprotein by airway proteases enhances virus entry into human bronchial epithelial cells in vitro. PLoS ONE 2009, 4, e7870. [CrossRef]

42. Matsuyama, S.; Ujike, M.; Morikawa, S.; Tashiro, M.; Taguchi, F. Protease-mediated enhancement of severe acute respiratory syndrome coronavirus infection. Proc. Natl. Acad. Sci. USA 2005, 102, 12543-12547. [CrossRef]

43. Li, F. Receptor Recognition Mechanisms of Coronaviruses: A Decade of Structural Studies. J. Virol. 2014, 89, 1954-1964. [CrossRef]

44. Li, W.; Moore, M.J.; Vasilieva, N.; Sui, J.; Wong, S.K.; Berne, M.A.; Somasundaran, M.; Sullivan, J.L.; Luzuriaga, K.; Greenough, T.C.; et al. Angiotensin-converting enzyme 2 is a functional receptor for the SARS coronavirus. Nature 2003, 426, 450-454. [CrossRef]

45. Hoffmann, M.; Kleine-Weber, H.; Schroeder, S.; Krüger, N.; Herrler, T.; Erichsen, S.; Schiergens, T.S.; Herrler, G.; $\mathrm{Wu}$, N.-H.; Nitsche, A.; et al. SARS-CoV-2 Cell Entry Depends on ACE2 and TMPRSS2 and is blocked by a clinically proven protease inhibitor. Cell 2020, 181, 271-280.e8. [CrossRef]

46. Yang, N.; Shen, H.-M. Targeting the Endocytic Pathway and Autophagy Process as a Novel Therapeutic Strategy in COVID-19. Int. J. Boil. Sci. 2020, 16, 1724-1731. [CrossRef]

47. Wan, Y.; Shang, J.; Graham, R.; Baric, R.S.; Li, F. Receptor recognition by the novel coronavirus from Wuhan: An analysis based on decade-long structural studies of sars coronavirus. J. Virol. 2020, 94, 94. [CrossRef] [PubMed]

48. Li, W.; Zhang, C.; Sui, J.; Kuhn, J.H.; Moore, M.J.; Luo, S.; Wong, S.-K.; Huang, I.-C.; Xu, K.; Vasilieva, N.; et al. Receptor and viral determinants of SARS-coronavirus adaptation to human ACE2. EMBO J. 2005, 24, 1634-1643. [CrossRef] [PubMed]

49. Åkerström, S.; Mirazimi, A.; Tan, Y.-J. Inhibition of SARS-CoV replication cycle by small interference RNAs silencing specific SARS proteins, 7a/7b, 3a/3b and S. Antivir. Res. 2007, 73, 219-227. [CrossRef] [PubMed]

50. Simmons, G.; Gosalia, D.N.; Rennekamp, A.J.; Reeves, J.D.; Diamond, S.L.; Bates, P. Inhibitors of cathepsin L prevent severe acute respiratory syndrome coronavirus entry. Proc. Natl. Acad. Sci. USA 2005, 102, 11876-11881. [CrossRef]

51. Weiss, S.R.; Navas, S. Coronavirus pathogenesis and the emerging pathogen severe acute respiratory syndrome coronavirus. Microbiol. Mol. Boil. Rev. 2005, 69, 635-664. [CrossRef]

52. Inoue, Y.; Tanaka, N.; Tanaka, Y.; Inoue, S.; Morita, K.; Zhuang, M.; Hattori, T.; Sugamura, K. Clathrin-Dependent entry of severe acute respiratory syndrome coronavirus into target cells expressing ACE2 with the cytoplasmic tail deleted. J. Virol. 2007, 81, 8722-8729. [CrossRef]

53. Bonow, R.O.; Fonarow, G.C.; O'Gara, P.T.; Yancy, C.W. Association of Coronavirus Disease 2019 (COVID-19) with myocardial injury and mortality. JAMA Cardiol. 2020. [CrossRef]

54. Tan, W.; Aboulhosn, J. The cardiovascular burden of coronavirus disease 2019 (COVID-19) with a focus on congenital heart disease. Int. J. Cardiol. 2020, 309, 70-77. [CrossRef]

55. Bunyavanich, S.; Do, A.; Vicencio, A. Nasal gene expression of angiotensin-converting Enzyme 2 in children and adults. JAMA 2020, 323, 2427. [CrossRef]

56. Wu, A.; Peng, Y.; Huang, B.; Ding, X.; Wang, X.; Niu, P.; Meng, J.; Zhu, Z.; Zhang, Z.; Wang, J.; et al. Genome composition and divergence of the novel coronavirus (2019-nCoV) originating in China. Cell Host Microbe 2020, 27, 325-328. [CrossRef]

57. Yan, R.; Zhang, Y.; Li, Y.; Xia, L.; Guo, Y.; Zhou, Q. Structural basis for the recognition of SARS-CoV-2 by full-length human ACE2. Science 2020, 367, 1444-1448. [CrossRef] [PubMed]

58. Shang, J.; Ye, G.; Shi, K.; Wan, Y.; Luo, C.; Aihara, H.; Geng, Q.; Auerbach, A.; Li, F. Structural basis of receptor recognition by SARS-CoV-2. Nature 2020, 581, 221-224. [CrossRef]

59. Gheblawi, M.; Wang, K.; Viveiros, A.; Nguyen, Q.; Zhong, J.-C.; Turner, A.J.; Raizada, M.K.; Grant, M.B.; Oudit, G.Y. Angiotensin-Converting Enzyme 2: SARS-CoV-2 Receptor and regulator of the renin-angiotensin system. Circ. Res. 2020, 126, 1456-1474. [CrossRef] [PubMed]

60. Skeggs, L.T.; Dorer, F.E.; Levine, M.; Lentz, K.E.; Kahn, J.R. The biochemistry of the renin-angiotensin system. Adv. Exp. Med. Biol. 1980, 130, 1-27. [CrossRef] [PubMed] 
61. Johnston, C. Angiotensin converting enzyme inhibition. In The Renin-Angiotensin System; Robertson, J., Nichols, M.G., Eds.; Gower Medical Pub: London, UK, 1993; Volume 1.

62. Funder, J.W. Aldosterone and mineralocorticoid receptors-Physiology and pathophysiology. Int. J. Mol. Sci. 2017, 18, 1032. [CrossRef]

63. Campbell, D.J. Circulating and tissue angiotensin systems. J. Clin. Investig. 1987, 79, 1-6. [CrossRef]

64. Campbell, D.J. Tissue renin-angiotensin system. J. Cardiovasc. Pharmacol. 1987, 10 (Suppl. 7), S1-S8. [CrossRef]

65. Phillips, M.I.; Speakman, E.A.; Kimura, B. Levels of angiotensin and molecular biology of the tissue renin angiotensin systems. Regul. Pept. 1993, 43, 1-20. [CrossRef]

66. Romero, C.A.; Orias, M.; Weir, M.R. Novel RAAS agonists and antagonists: Clinical applications and controversies. Nat. Rev. Endocrinol. 2015, 11, 242-252. [CrossRef]

67. Patel, S.; Rauf, A.; Khan, H.; Abu-Izneid, T. Renin-angiotensin-aldosterone (RAAS): The ubiquitous system for homeostasis and pathologies. Biomed. Pharmacother. 2017, 94, 317-325. [CrossRef]

68. Santos, R.A.S.; Sampaio, W.O.; Alzamora, A.C.; Motta-Santos, D.; Alenina, N.; Bader, M.; Campagnole-Santos, M.J. The ACE2/Angiotensin-(1-7)/MAS Axis of the Renin-Angiotensin System: Focus on Angiotensin-(1-7). Physiol. Rev. 2018, 98, 505-553. [CrossRef] [PubMed]

69. Hofmann, H.; Pyrc, K.; Van Der Hoek, L.; Geier, M.; Berkhout, B.; Pöhlmann, S. Human coronavirus NL63 employs the severe acute respiratory syndrome coronavirus receptor for cellular entry. Proc. Natl. Acad. Sci. 2005, 102, 7988-7993. [CrossRef] [PubMed]

70. Liu, Y.; Yang, Y.; Zhang, C.; Huang, F.; Wang, F.; Yuan, J.; Wang, Z.; Li, J.; Li, J.; Feng, C.; et al. Clinical and biochemical indexes from 2019-nCoV infected patients linked to viral loads and lung injury. Sci. China Life Sci. 2020, 63, 364-374. [CrossRef] [PubMed]

71. Imai, Y.; Kuba, K.; Rao, S.; Huan, Y.; Guo, F.; Guan, B.; Yang, P.; Sarao, R.; Wada, T.; Leong-Poi, H.; et al. Angiotensin-converting enzyme 2 protects from severe acute lung failure. Nature 2005, 436, 112-116. [CrossRef]

72. Kuba, K.; Imai, Y.; Rao, S.; Gao, H.; Guo, F.; Guan, B.; Huan, Y.; Yang, P.; Zhang, Y.; Deng, W.; et al. A crucial role of angiotensin converting enzyme 2 (ACE2) in SARS coronavirus-induced lung injury. Nat. Med. 2005, 11, 875-879. [CrossRef]

73. Burrell, L.M.; Johnston, C.I.; Tikellis, C.; Cooper, M.E. ACE2, a new regulator of the renin-angiotensin system. Trends Endocrinol. Metab. 2004, 15, 166-169. [CrossRef]

74. Donoghue, M.; Hsieh, F.; Baronas, E.; Godbout, K.; Gosselin, M.; Stagliano, N.; Donovan, M.; Woolf, B.; Robison, K.; Jeyaseelan, R.; et al. A novel angiotensin-converting enzyme-related carboxypeptidase (ACE2) converts angiotensin I to angiotensin 1-9. Circ. Res. 2000, 87, e1-e9. [CrossRef]

75. Tipnis, S.R.; Hooper, N.M.; Hyde, R.; Karran, E.; Christie, G.; Turner, A.J. A Human Homolog of Angiotensin-converting Enzyme. J. Boil. Chem. 2000, 275, 33238-33243. [CrossRef]

76. Fraga-Silva, R.A.; Costa-Fraga, F.P.; Murça, T.M.; Moraes, P.L.; Lima, A.M.; Lautner, R.Q.; Castro, C.H.; Soares, C.M.A.; Borges, C.L.; Nadu, A.P.; et al. Angiotensin-converting enzyme 2 activation improves endothelial function. Hypertension 2013, 61, 1233-1238. [CrossRef]

77. Prestes, T.R.R.; Rocha, N.P.; Miranda, A.S.; Teixeira, A.L.; Simões-E-Silva, A.C.; Prestes, N.P.R.T.R.R. The Anti-Inflammatory Potential of ACE2/Angiotensin-(1-7)/Mas Receptor Axis: Evidence from Basic and Clinical Research. Curr. Drug Targets 2017, 18, 1301-1313. [CrossRef]

78. The Human Protein Atlas. Angiotensin I Converting Enzyme. Available online: https://www.proteinatlas. org/ENSG00000159640-ACE (accessed on 24 April 2020).

79. The Human Protein Atlas. Tissue Expression of ACE2. Available online: https://www.proteinatlas.org/ ENSG00000130234-ACE2/tissue (accessed on 24 April 2020).

80. Chai, X.; Hu, L.; Zhang, Y.; Han, W.; Lu, Z.; Ke, A.; Zhou, J.; Shi, G.; Fang, N.; Fan, J.; et al. Specific ACE2 Expression in Cholangiocytes May Cause Liver Damage After 2019-nCoV Infection. bioRxiv 2020. [CrossRef]

81. Crackower, M.A.; Sarao, R.; Oudit, G.Y.; Yagil, C.; Kozieradzki, I.; Scanga, S.E.; Oliveira-Dos-Santos, A.J.; Da Costa, J.; Zhang, L.; Pei, Y.; et al. Angiotensin-converting enzyme 2 is an essential regulator of heart function. Nature 2002, 417, 822-828. [CrossRef] [PubMed]

82. Hamming, I.; Timens, W.; Bulthuis, M.; Lely, A.T.; Navis, G.; Van Goor, H. Tissue distribution of ACE2 protein, the functional receptor for SARS coronavirus. A first step in understanding SARS pathogenesis. J. Pathol. 2004, 203, 631-637. [CrossRef] [PubMed] 
83. Tikellis, C.; Johnston, C.I.; Forbes, J.M.; Burns, W.C.; Burrell, L.M.; Risvanis, J.; Cooper, M.E. Characterization of Renal Angiotensin-Converting Enzyme 2 in Diabetic Nephropathy. Hypertension 2003, 41, $392-397$. [CrossRef] [PubMed]

84. Zou, X.; Chen, K.; Zou, J.; Han, P.; Hao, J.; Han, Z.-G. Single-cell RNA-seq data analysis on the receptor ACE2 expression reveals the potential risk of different human organs vulnerable to 2019-nCoV infection. Front. Med. 2020, 14, 185-192. [CrossRef] [PubMed]

85. Zhang, H.; Kang, Z.; Gong, H.; Xu, D.; Wang, J.; Li, Z.; Cui, X.; Xiao, J.; Meng, T.; Zhou, W.; et al. The digestive system is a potential route of 2019-nCov infection: A bioinformatics analysis based on single-cell transcriptomes. bioRxiv 2020. [CrossRef]

86. Jia, H.P.; Look, D.C.; Shi, L.; Hickey, M.; Pewe, L.; Netland, J.; Farzan, M.; Wohlford-Lenane, C.; Perlman, S.; McCray, P.B. ACE2 Receptor expression and severe acute respiratory syndrome coronavirus infection depend on differentiation of human airway epithelia. J. Virol. 2005, 79, 14614-14621. [CrossRef]

87. Zhao, Y.; Zhao, Z.; Wang, Y.; Zhou, Y.; Ma, Y.; Zuo, W. Single-cell RNA expression profiling of ACE2, the putative receptor of Wuhan 2019-nCov. bioRxiv 2001. [CrossRef]

88. Xu, H.; Zhong, L.; Deng, J.; Peng, J.; Dan, H.; Zeng, X.; Li, T.; Chen, Q. High expression of ACE2 receptor of 2019-nCoV on the epithelial cells of oral mucosa. Int. J. Oral Sci. 2020, 12, 8. [CrossRef]

89. Brann, D.; Tsukahara, T.; Weinreb, C.; Logan, D.W.; Datta, S.R. Non-neural expression of SARS-CoV-2 entry genes in the olfactory epithelium suggests mechanisms underlying anosmia in COVID-19 patients. bioRxiv 2020. [CrossRef]

90. Guan, W.-j.; Ni, Z.-y.; Hu, Y.; Liang, W.-h.; Ou, C.-q.; He, J.-x.; Liu, L.; Shan, H.; Lei, C.-1.; Hui, D.S.; et al. Clinical characteristics of 2019 novel coronavirus infection in China. medRxiv 2020. [CrossRef]

91. Hashimoto, T.; Perlot, T.; Rehman, A.; Trichereau, J.; Ishiguro, H.; Paolino, M.; Sigl, V.; Hanada, T.; Hanada, R.; Lipinski, S.; et al. ACE2 links amino acid malnutrition to microbial ecology and intestinal inflammation. Nature 2012, 487, 477-481. [CrossRef] [PubMed]

92. Leung, W.K.; To, K.-F.; Chan, P.K.; Chan, H.L.; Wu, A.K.; Lee, N.; Yuen, K.Y.; Sung, J.J. Enteric involvement of severe acute respiratory syndrome-associated coronavirus infection. Gastroenterol. 2003, 125, 1011-1017. [CrossRef]

93. Haga, S.; Nagata, N.; Okamura, T.; Yamamoto, N.; Sata, T.; Yamamoto, N.; Sasazuki, T.; Ishizaka, Y. TACE antagonists blocking ACE2 shedding caused by the spike protein of SARS-CoV are candidate antiviral compounds. Antivir. Res. 2010, 85, 551-555. [CrossRef]

94. Heurich, A.; Hofmann-Winkler, H.; Gierer, S.; Liepold, T.; Jahn, O.; Pöhlmann, S. TMPRSS2 and ADAM17 Cleave ACE2 differentially and only proteolysis by TMPRSS2 augments entry driven by the severe acute respiratory syndrome coronavirus spike protein. J. Virol. 2014, 88, 1293-1307. [CrossRef] [PubMed]

95. Zunke, F.; Rose-John, S. The shedding protease ADAM17: Physiology and pathophysiology. Biochim. et Biophys. Acta (BBA)-Bioenerg. 2017, 1864, 2059-2070. [CrossRef]

96. E Sama, I.; Ravera, A.; Santema, B.T.; Van Goor, H.; Ter Maaten, J.M.; Cleland, J.G.F.; Rienstra, M.; Friedrich, A.W.; Samani, N.J.; Ng, L.L.; et al. Circulating plasma concentrations of angiotensin-converting enzyme 2 in men and women with heart failure and effects of renin-angiotensin-aldosterone inhibitors. Eur. Hear. J. 2020, 41, 1810-1817. [CrossRef]

97. Wang, K.; Gheblawi, M.; Oudit, G.Y. Angiotensin Converting Enzyme 2: A Double-Edged Sword. Circulation 2020. [CrossRef]

98. Clarke, N.E.; Belyaev, N.D.; Lambert, D.W.; Turner, A.J. Epigenetic regulation of angiotensin-converting enzyme 2 (ACE2) by SIRT1 under conditions of cell energy stress. Clin. Sci. (Lond). 2014, 126, 507-516. [CrossRef]

99. Gallagher, P.E.; Ferrario, C.M.; Tallant, E.A. Regulation of ACE2 in cardiac myocytes and fibroblasts. Am. J. Physiol. Heart Circ. Physiol. 2008, 295, H2373-H2379. [CrossRef]

100. Clarke, N.E.; Turner, A.J. Angiotensin-converting enzyme 2: The first decade. Int. J. Hypertens. 2012, 2012, 307315. [CrossRef] [PubMed]

101. Rice, G.I.; Jones, A.L.; Grant, P.J.; Carter, A.M.; Turner, A.J.; Hooper, N.M. Circulating activities of angiotensin-converting enzyme, its homolog, angiotensin-converting enzyme 2 , and neprilysin in a family study. Hypertension 2006, 48, 914-920. [CrossRef] [PubMed] 
102. Varagic, J.; Ahmad, S.; Nagata, S.; Ferrario, C.M. ACE2: Angiotensin II/angiotensin-(1-7) balance in cardiac and renal injury. Curr. Hypertens. Rep. 2014, 16, 420. [CrossRef]

103. Cooper, M.E.; Johnston, C.I. Optimizing treatment of hypertension in patients with diabetes. JAMA 2000, 283, 3177-3179. [CrossRef] [PubMed]

104. Patel, V.B.; Zhong, J.C.; Grant, M.B.; Oudit, G.Y. Role of the ACE2/Angiotensin 1-7 Axis of the Renin-Angiotensin System in Heart Failure. Circ. Res. 2016, 118, 1313-1326. [CrossRef]

105. Alghamdi, I.G.; Hussain, I.I.; Almalki, S.S.; Alghamdi, M.S.; Alghamdi, M.M.; El-Sheemy, M.A. The pattern of Middle East respiratory syndrome coronavirus in Saudi Arabia: A descriptive epidemiological analysis of data from the Saudi Ministry of Health. Int. J. Gen. Med. 2014, 7, 417-423. [CrossRef]

106. Karlberg, J.; Chong, D.S.; Lai, W.Y. Do men have a higher case fatality rate of severe acute respiratory syndrome than women do? Am. J. Epidemiol. 2004, 159, 229-231. [CrossRef]

107. Chen, Y.Y.; Zhang, P.; Zhou, X.M.; Liu, D.; Zhong, J.C.; Zhang, C.J.; Jin, L.J.; Yu, H.M. Relationship between genetic variants of ACE2 gene and circulating levels of ACE2 and its metabolites. J. Clin. Pharm. Ther. 2018, 43, 189-195. [CrossRef]

108. Fan, X.; Wang, Y.; Sun, K.; Zhang, W.; Yang, X.; Wang, S.; Zhen, Y.; Wang, J.; Li, W.; Han, Y.; et al. Polymorphisms of ACE2 gene are associated with essential hypertension and antihypertensive effects of Captopril in women. Clin. Pharmacol. Ther. 2007, 82, 187-196. [CrossRef]

109. Hussain, M.; Jabeen, N.; Raza, F.; Shabbir, S.; Baig, A.A.; Amanullah, A.; Aziz, B. Structural variations in human ACE2 may influence its binding with SARS-CoV-2 spike protein. J. Med. Virol. 2020. [CrossRef]

110. Cao, Y.; Li, L.; Feng, Z.; Wan, S.; Huang, P.; Sun, X.; Wen, F.; Huang, X.; Ning, G.; Wang, W. Comparative genetic analysis of the novel coronavirus (2019-nCoV/SARS-CoV-2) receptor ACE2 in different populations. Cell Discov. 2020, 6, 11. [CrossRef] [PubMed]

111. Shenoy, V.; Grobe, J.L.; Qi, Y.; Ferreira, A.J.; Fraga-Silva, R.A.; Collamat, G.; Bruce, E.; Katovich, M.J. 17beta-Estradiol modulates local cardiac renin-angiotensin system to prevent cardiac remodeling in the DOCA-salt model of hypertension in rats. Peptides 2009, 30, 2309-2315. [CrossRef] [PubMed]

112. Bukowska, A.; Spiller, L.; Wolke, C.; Lendeckel, U.; Weinert, S.; Hoffmann, J.; Bornfleth, P.; Kutschka, I.; Gardemann, A.; Isermann, B.; et al. Protective regulation of the ACE2/ACE gene expression by estrogen in human atrial tissue from elderly men. Exp. Biol. Med. (Maywood) 2017, 242, 1412-1423. [CrossRef] [PubMed]

113. Channappanavar, R.; Fett, C.; Mack, M.; Ten Eyck, P.P.; Meyerholz, D.K.; Perlman, S. Sex-based differences in susceptibility to severe acute respiratory syndrome coronavirus infection. J. Immunol. 2017, 198, 4046-4053. [CrossRef] [PubMed]

114. Verdecchia, P.; Cavallini, C.; Spanevello, A.; Angeli, F. The pivotal link between ACE2 deficiency and SARS-CoV-2 infection. Eur. J. Intern. Med. 2020. [CrossRef]

115. Zou, Z.; Yan, Y.; Shu, Y.; Gao, R.; Sun, Y.; Li, X.; Ju, X.; Liang, Z.; Liu, Q.; Zhao, Y.; et al. Angiotensin-converting enzyme 2 protects from lethal avian influenza A H5N1 infections. Nat. Commun. 2014, 5, 3594. [CrossRef]

116. Bodor, C.; Nagy, J.; Végh, B.; Nemeth, A.; Jenei, A.; Mirzahosseini, S.; Sebe, A.; Rosivall, L. Angiotensin II increases the permeability and PV-1 expression of endothelial cells. Am. J. Physiol. Cell Physiol. 2012, 302, C267-C276. [CrossRef]

117. Elferink, J.G.; de Koster, B.M. The stimulation of human neutrophil migration by angiotensin IL: Its dependence on Ca2+ and the involvement of cyclic GMP. Br. J. Pharmacol. 1997, 121, 643-648. [CrossRef]

118. Guzik, T.J.; Hoch, N.E.; Brown, K.A.; McCann, L.A.; Rahman, A.; Dikalov, S.; Goronzy, J.; Weyand, C.; Harrison, D.G. Role of the $\mathrm{T}$ cell in the genesis of angiotensin II induced hypertension and vascular dysfunction. J. Exp. Med. 2007, 204, 2449-2460. [CrossRef]

119. Jurewicz, M.; McDermott, D.H.; Sechler, J.M.; Tinckam, K.; Takakura, A.; Carpenter, C.B.; Milford, E.; Abdi, R. Human $\mathrm{T}$ and natural killer cells possess a functional renin-angiotensin system: Further mechanisms of angiotensin II-induced inflammation. J. Am. Soc. Nephrol. 2007, 18, 1093-1102. [CrossRef]

120. Lijnen, P.; Fagard, R.; Petrov, V. Cytosolic calcium changes induced by angiotensin II in human peripheral blood mononuclear cells are mediated via angiotensin II subtype 1 receptors. J. Hypertens. 1997, 15, 871-876. [CrossRef] [PubMed]

121. Nahmod, K.A.; Vermeulen, M.E.; Raiden, S.; Salamone, G.; Gamberale, R.; Fernández-Calotti, P.; Alvarez, A.; Nahmod, V.; Giordano, M.; Geffner, J.R. Control of dendritic cell differentiation by angiotensin II. FASEB J. 2003, 17, 491-493. [CrossRef] [PubMed] 
122. Nataraj, C.; Oliverio, M.I.; Mannon, R.B.; Mannon, P.J.; Audoly, L.P.; Amuchastegui, C.S.; Ruiz, P.; Smithies, O.; Coffman, T.M. Angiotensin II regulates cellular immune responses through a calcineurin-dependent pathway. J. Clin. Investig. 1999, 104, 1693-1701. [CrossRef] [PubMed]

123. Phillips, M.I.; Kagiyama, S. Angiotensin II as a pro-inflammatory mediator. Curr. Opin. Investig. Drugs 2002, 3, 569-577. [PubMed]

124. Platten, M.; Youssef, S.; Hur, E.M.; Ho, P.P.; Han, M.H.; Lanz, T.V.; Phillips, L.K.; Goldstein, M.J.; Bhat, R.; Raine, C.S.; et al. Blocking angiotensin-converting enzyme induces potent regulatory T cells and modulates TH1- and TH17-mediated autoimmunity. Proc. Natl. Acad. Sci. USA 2009, 106, 14948-14953. [CrossRef]

125. Sadoshima, J. Cytokine actions of angiotensin II. Circ. Res. 2000, 86, 1187-1189. [CrossRef]

126. Swirski, F.K.; Nahrendorf, M.; Etzrodt, M.; Wildgruber, M.; Cortez-Retamozo, V.; Panizzi, P.; Figueiredo, J.L.; Kohler, R.H.; Chudnovskiy, A.; Waterman, P.; et al. Identification of splenic reservoir monocytes and their deployment to inflammatory sites. Science 2009, 325, 612-616. [CrossRef]

127. Lau, Y.L.; Peiris, J.S. Pathogenesis of severe acute respiratory syndrome. Curr. Opin. Immunol. 2005, 17, 404-410. [CrossRef]

128. Perlman, S.; Dandekar, A.A. Immunopathogenesis of coronavirus infections: Implications for SARS. Nat. Rev. Immunol. 2005, 5, 917-927. [CrossRef]

129. Zhang, H.; Penninger, J.M.; Li, Y.; Zhong, N.; Slutsky, A.S. Angiotensin-converting enzyme 2 (ACE2) as a SARS-CoV-2 receptor: Molecular mechanisms and potential therapeutic target. Intensiv. Care Med. 2020, 46, 586-590. [CrossRef]

130. Zheng, Y.-Y.; Ma, Y.-T.; Zhang, J.-Y.; Xie, X. COVID-19 and the cardiovascular system. Nat. Rev. Cardiol. 2020, 17, 259-260. [CrossRef] [PubMed]

131. Byrnes, J.J.; Gross, S.; Ellard, C.; Connolly, K.; Donahue, S.; Picarella, D. Effects of the ACE2 inhibitor GL1001 on acute dextran sodium sulfate-induced colitis in mice. Inflamm. Res. 2009, 58, 819-827. [CrossRef] [PubMed]

132. Towler, P.; Staker, B.; Prasad, S.G.; Menon, S.; Tang, J.; Parsons, T.; Ryan, D.; Fisher, M.; Williams, D.; Dales, N.A.; et al. ACE2 X-ray structures reveal a large hinge-bending motion important for inhibitor binding and catalysis. J. Biol. Chem. 2004, 279, 17996-18007. [CrossRef] [PubMed]

133. Clarke, N.E.; Hooper, N.M.; Turner, A.J. Angiotensin-converting enzyme-2. Handb. Proteolytic Enzym. 2013, 499.

134. Hernández Prada, J.A.; Ferreira, A.J.; Katovich, M.J.; Shenoy, V.; Qi, Y.; Santos, R.A.; Castellano, R.K.; Lampkins, A.J.; Gubala, V.; Ostrov, D.A.; et al. Structure-based identification of small-molecule angiotensin-converting enzyme 2 activators as novel antihypertensive agents. Hypertension 2008, 51, 1312-1317. [CrossRef] [PubMed]

135. Takahashi, Y.; Haga, S.; Ishizaka, Y.; Mimori, A. Autoantibodies to angiotensin-converting enzyme 2 in patients with connective tissue diseases. Arthritis. Res. Ther. 2010, 12, R85. [CrossRef] [PubMed]

136. Bryan, J. From snake venom to ACE inhibitor-The discovery and rise of captopril. Pharm. J. 2009, $282,455$.

137. Heran, B.S.; Wong, M.M.; Heran, I.K.; Wright, J.M. Blood pressure lowering efficacy of angiotensin converting enzyme (ACE) inhibitors for primary hypertension. Cochrane Database Syst. Rev. 2008, 2008, Cd003823. [CrossRef]

138. Campbell, D.J.; Lawrence, A.C.; Towrie, A.; Kladis, A.; Valentijn, A.J. Differential regulation of angiotensin peptide levels in plasma and kidney of the rat. Hypertension 1991, 18, 763-773. [CrossRef]

139. Ohkubo, H.; Nakayama, K.; Tanaka, T.; Nakanishi, S. Tissue distribution of rat angiotensinogen mRNA and structural analysis of its heterogeneity. J. Biol. Chem. 1986, 261, 319-323. [PubMed]

140. Bader, M.; Peters, J.; Baltatu, O.; Müller, D.N.; Luft, F.C.; Ganten, D. Tissue renin-angiotensin systems: New insights from experimental animal models in hypertension research. J. Mol. Med. (Berl. Germany) 2001, 79, 76-102. [CrossRef] [PubMed]

141. Engeli, S.; Negrel, R.; Sharma, A.M. Physiology and pathophysiology of the adipose tissue renin-angiotensin system. Hypertension 2000, 35, 1270-1277. [CrossRef] [PubMed]

142. Morimoto, S.; Sigmund, C.D. Angiotensin mutant mice: A focus on the brain renin-angiotensin system. Neuropeptides 2002, 36, 194-200. [CrossRef] [PubMed]

143. Sernia, C. A critical appraisal of the intrinsic pancreatic angiotensin-generating system. JOP 2001, 2, 50-55. [PubMed] 
144. Dzau, V.J.; Bernstein, K.; Celermajer, D.; Cohen, J.; Dahlöf, B.; Deanfield, J.; Diez, J.; Drexler, H.; Ferrari, R.; van Gilst, W.; et al. The relevance of tissue angiotensin-converting enzyme: Manifestations in mechanistic and endpoint data. Am. J. Cardiol. 2001, 88, 11-201. [CrossRef]

145. Ranadive, S.A.; Chen, A.X.; Serajuddin, A.T. Relative lipophilicities and structural-pharmacological considerations of various angiotensin-converting enzyme (ACE) inhibitors. Pharm. Res. 1992, 9, 1480-1486. [CrossRef]

146. Singh, K.D.; Karnik, S.S. Angiotensin Receptors: Structure, function, signaling and clinical applications. J. Cell Signal. 2016, 1, 111. [CrossRef]

147. Guimond, M.-O.; Hallberg, M.; Gallo-Payet, N.; Wallinder, C. Saralasin and Sarile Are AT2 receptor agonists. ACS Med. Chem. Lett. 2014, 5, 1129-1132. [CrossRef]

148. Moore, A.F.; Fulton, R.W. Angiotensin II antagonists-saralasin. Drug Dev. Res. 1984, 4, 331-349. [CrossRef]

149. Yang, R.; Luo, Z.; Liu, Y.; Sun, M.; Zheng, L.; Chen, Y.; Li, Y.; Wang, H.; Chen, L.; Wu, M.; et al. Drug interactions with angiotensin receptor blockers: role of human cytochromes P450. Curr. Drug Metab. 2016, 17, 681-691. [CrossRef]

150. Siragy, H.M. Angiotensin receptor blockers: How important is selectivity? Am. J. Hypertens. 2002, 15, 1006-1014. [CrossRef]

151. Suwannakul, S.; Ieiri, I.; Kimura, M.; Kawabata, K.; Kusuhara, H.; Hirota, T.; Irie, S.; Sugiyama, Y.; Higuchi, S. Pharmacokinetic interaction between pravastatin and olmesartan in relation to SLCO1B1 polymorphism. J. Hum. Genet. 2008, 53, 899-904. [CrossRef]

152. De Kloet, E.R.; Vreugdenhil, E.; Oitzl, M.S.; Joëls, M. Brain corticosteroid receptor balance in health and disease. Endocr. Rev. 1998, 19, 269-301. [CrossRef]

153. Funder, J.W. Mineralocorticoid receptors: Distribution and activation. Heart Fail. Rev. 2005, 10, 15-22. [CrossRef] [PubMed]

154. Gomez-Sanchez, C.E.; Warden, M.; Gomez-Sanchez, M.T.; Hou, X.; Gomez-Sanchez, E.P. Diverse immunostaining patterns of mineralocorticoid receptor monoclonal antibodies. Steroids 2011, 76, 1541-1545. [CrossRef] [PubMed]

155. Sica, D.A. Pharmacokinetics and pharmacodynamics of mineralocorticoid blocking agents and their effects on potassium homeostasis. Heart Fail. Rev. 2005, 10, 23-29. [CrossRef]

156. Levy, D.G.; Rocha, R.; Funder, J.W. Distinguishing the antihypertensive and electrolyte effects of eplerenone. J. Clin. Endocrinol. Metab. 2004, 89, 2736-2740. [CrossRef]

157. Tolbert, D.; Reid, S.; Roniker, B. Pharmacokinetics of eplerenone coadministered with other medications. Pharmacotherapy 2020, 22, 1331.

158. Pitt, B.; Remme, W.; Zannad, F.; Neaton, J.; Martinez, F.; Roniker, B.; Bittman, R.; Hurley, S.; Kleiman, J.; Gatlin, M. Eplerenone, a selective aldosterone blocker, in patients with left ventricular dysfunction after myocardial infarction. N. Engl. J. Med. 2003, 348, 1309-1321. [CrossRef]

159. Pitt, B.; Zannad, F.; Remme, W.J.; Cody, R.; Castaigne, A.; Perez, A.; Palensky, J.; Wittes, J. The effect of spironolactone on morbidity and mortality in patients with severe heart failure. Randomized Aldactone Evaluation Study Investigators. N. Engl. J. Med. 1999, 341, 709-717. [CrossRef]

160. Vaidyanathan, S.; Jarugula, V.; Dieterich, H.A.; Howard, D.; Dole, W.P. Clinical pharmacokinetics and pharmacodynamics of aliskiren. Clin. Pharmacokinet. 2008, 47, 515-531. [CrossRef] [PubMed]

161. Azizi, M.; Webb, R.; Nussberger, J.; Hollenberg, N.K. Renin inhibition with aliskiren: Where are we now, and where are we going? J. Hypertens. 2006, 24, 243-256. [CrossRef] [PubMed]

162. Lijnen, P.; Fagard, R.; Staessen, J.; Amery, A. Effect of chronic diuretic treatment on the plasma renin-angiotensin-aldosterone system in essential hypertension. Br. J. Clin. Pharmacol. 1981, 12, 387-392. [CrossRef] [PubMed]

163. Wu, Z.; McGoogan, J.M. Characteristics of and important lessons from the coronavirus disease 2019 (COVID-19) outbreak in China: Summary of a report of 72314 cases from the Chinese center for disease control and prevention. JAMA 2020, 13, 1239-1242. [CrossRef]

164. Arai, T.; Yasuda, Y.; Takaya, T.; Toshima, S.; Kashiki, Y.; Shibayama, M.; Yoshimi, N.; Fujiwara, H. Angiotensin-converting enzyme inhibitors, angiotensin-II receptor antagonists, and pneumonia in elderly hypertensive patients with stroke. Chest 2001, 119, 660-661. [CrossRef] [PubMed] 
165. Kikuchi, R.; Watabe, N.; Konno, T.; Mishina, N.; Sekizawa, K.; Sasaki, H. High incidence of silent aspiration in elderly patients with community-acquired pneumonia. Am. J. Respir. Crit. Care Med. 1994, 150, 251-253. [CrossRef] [PubMed]

166. Sekizawa, K.; Ujiie, Y.; Itabashi, S.; Sasaki, H.; Takishima, T. Lack of cough reflex in aspiration pneumonia. Lancet 1990, 335, 1228-1229. [CrossRef]

167. Arai, T.; Yasuda, Y.; Takaya, T.; Toshima, S.; Kashiki, Y.; Yoshimi, N.; Fujiwara, H. ACE inhibitors and symptomless dysphagia. Lancet 1998, 352, 115-116. [CrossRef]

168. Arai, T.; Yoshimi, N.; Fujiwara, H.; Sekizawa, K. Serum substance P concentrations and silent aspiration in elderly patients with stroke. Neurology 2003, 61, 1625-1626. [CrossRef]

169. El Bekay, R.; Alvarez, M.; Monteseirín, J.; Alba, G.; Chacón, P.; Vega, A.; Martin-Nieto, J.; Jiménez, J.; Pintado, E.; Bedoya, F.J.; et al. Oxidative stress is a critical mediator of the angiotensin II signal in human neutrophils: Involvement of mitogen-activated protein kinase, calcineurin, and the transcription factor NF-kappaB. Blood 2003, 102, 662-671. [CrossRef]

170. Fernandez-Castelo, S.; Arzt, E.S.; Pesce, A.; Criscuolo, M.E.; Diaz, A.; Finkielman, S.; Nahmod, V.E. Angiotensin II regulates interferon-gamma production. J. Interferon. Res. 1987, 7, 261-268. [CrossRef] [PubMed]

171. Fukuzawa, M.; Satoh, J.; Sagara, M.; Muto, G.; Muto, Y.; Nishimura, S.; Miyaguchi, S.; Qiang, X.L.; Sakata, Y.; Nakazawa, T.; et al. Angiotensin converting enzyme inhibitors suppress production of tumor necrosis factor-alpha in vitro and in vivo. Immunopharmacology 1997, 36, 49-55. [CrossRef]

172. Hernández-Presa, M.; Bustos, C.; Ortego, M.; Tuñon, J.; Renedo, G.; Ruiz-Ortega, M.; Egido, J. Angiotensin-converting enzyme inhibition prevents arterial nuclear factor-kappa B activation, monocyte chemoattractant protein-1 expression, and macrophage infiltration in a rabbit model of early accelerated atherosclerosis. Circulation 1997, 95, 1532-1541. [CrossRef] [PubMed]

173. Kranzhöfer, R.; Browatzki, M.; Schmidt, J.; Kübler, W. Angiotensin II activates the proinflammatory transcription factor nuclear factor-kappaB in human monocytes. Biochem. Biophys. Res. Commun. 1999, 257, 826-828. [CrossRef] [PubMed]

174. Nahmod, K.A.; Nahmod, V.E.; Szvalb, A.D. Potential mechanisms of AT1 receptor blockers on reducing pneumonia-related mortality. Clin. Infect. Dis. 2013, 56, 1193-1194. [CrossRef]

175. Arai, T.; Sekizawa, K.; Ohrui, T.; Fujiwara, H.; Yoshimi, N.; Matsuoka, H.; Sasaki, H. ACE inhibitors and protection against pneumonia in elderly patients with stroke. Neurology 2005, 64, 573-574. [CrossRef]

176. Ohkubo, T.; Chapman, N.; Neal, B.; Woodward, M.; Omae, T.; Chalmers, J. Effects of an angiotensin-converting enzyme inhibitor-based regimen on pneumonia risk. Am. J. Respir. Crit. Care Med. 2004, 169, 1041-1045. [CrossRef]

177. Okaishi, K.; Morimoto, S.; Fukuo, K.; Niinobu, T.; Hata, S.; Onishi, T.; Ogihara, T. Reduction of risk of pneumonia associated with use of angiotensin I converting enzyme inhibitors in elderly inpatients. Am. J. Hypertens. 1999, 12, 778-783. [CrossRef]

178. Etminan, M.; Zhang, B.; Fitzgerald, M.; Brophy, J.M. Do angiotensin-converting enzyme inhibitors or angiotensin II receptor blockers decrease the risk of hospitalization secondary to community-acquired pneumonia? A nested case-control study. Pharmacotherapy 2006, 26, 479-482. [CrossRef]

179. Mortensen, E.M.; Restrepo, M.I.; Anzueto, A.; Pugh, J. The impact of prior outpatient ACE inhibitor use on 30-day mortality for patients hospitalized with community-acquired pneumonia. BMC Pulm. Med. 2005, 5, 12. [CrossRef]

180. van de Garde, E.M.; Souverein, P.C.; Hak, E.; Deneer, V.H.; van den Bosch, J.M.; Leufkens, H.G. Angiotensin-converting enzyme inhibitor use and protection against pneumonia in patients with diabetes. J. Hypertens. 2007, 25, 235-239. [CrossRef] [PubMed]

181. Liappis, A.P.; Kan, V.L.; Rochester, C.G.; Simon, G.L. The effect of statins on mortality in patients with bacteremia. Clin. Infect. Dis. 2001, 33, 1352-1357. [CrossRef] [PubMed]

182. Mortensen, E.M.; Restrepo, M.I.; Copeland, L.A.; Pugh, J.A.; Anzueto, A. Association of hydrophilic versus lipophilic angiotensin-converting enzyme inhibitor use on pneumonia-related mortality. Am. J. Med. Sci. 2008, 336, 462-466. [CrossRef]

183. Mortensen, E.M.; Nakashima, B.; Cornell, J.; Copeland, L.A.; Pugh, M.J.; Anzueto, A.; Good, C.; Restrepo, M.I.; Downs, J.R.; Frei, C.R.; et al. Population-based study of statins, angiotensin II receptor blockers, and 
angiotensin-converting enzyme inhibitors on pneumonia-related outcomes. Clin. Infect. Dis. 2012, 55, 1466-1473. [CrossRef] [PubMed]

184. Liu, C.-L.; Shau, W.-Y.; Chang, C.-H.; Wu, C.-S.; Lai, M.-S. Pneumonia risk and use of angiotensin-converting enzyme inhibitors and angiotensin II receptor blockers. J. Epidemiol. 2013, 23, 344-350. [CrossRef]

185. Soto, M.; Bang, S.I.; McCombs, J.; Rodgers, K.E. Renin Angiotensin system-modifying therapies are associated with improved pulmonary health. Clin. Diabetes Endocrinol. 2017, 3, 6. [CrossRef]

186. Caldeira, D.; Alarcão, J.; Vaz-Carneiro, A.; Costa, J. Risk of pneumonia associated with use of angiotensin converting enzyme inhibitors and angiotensin receptor blockers: Systematic review and meta-analysis. BMJ 2012, 345, e4260. [CrossRef]

187. Fedson, D.S. Treating the host response to emerging virus diseases: Lessons learned from sepsis, pneumonia, influenza and Ebola. Ann. Transl. Med. 2016, 4, 421. [CrossRef]

188. Reiner, Ž.; Hatamipour, M.; Banach, M.; Pirro, M.; Al-Rasadi, K.; Jamialahmadi, T.; Radenkovic, D.; Montecucco, F.; Sahebkar, A. Statins and the COVID-19 main protease: In silico evidence on direct interaction. Arch. Med. Sci. 2020, 16, 490-496. [CrossRef]

189. Rodrigues Díez, R.; Rodrigues-Díez, R.; Lavoz, C.; Rayego-Mateos, S.; Civantos, E.; Rodríguez-Vita, J.; Mezzano, S.; Ortiz, A.; Egido, J.; Ruiz-Ortega, M. Statins inhibit angiotensin II/Smad pathway and related vascular fibrosis, by a TGF- $\beta$-independent process. PLoS ONE 2010, 5, e14145. [CrossRef]

190. Aguilar, C.; Ventura, F.; Rodríguez-Delfín, L. [Atorvastatin induced increase in homologous angiotensin I converting enzyme (ACE2) mRNA is associated to decreased fibrosis and decreased left ventricular hypertrophy in a rat model of diabetic cardiomyopathy]. Rev. Peru. Med. Exp. Salud Publica 2011, 28, $264-272$. [CrossRef] [PubMed]

191. Li, Y.H.; Wang, Q.X.; Zhou, J.W.; Chu, X.M.; Man, Y.L.; Liu, P.; Ren, B.B.; Sun, T.R.; An, Y. Effects of rosuvastatin on expression of angiotensin-converting enzyme 2 after vascular balloon injury in rats. J. Geriatr. Cardiol. 2013, 10, 151-158. [CrossRef] [PubMed]

192. Shin, Y.H.; Min, J.J.; Lee, J.H.; Kim, E.H.; Kim, G.E.; Kim, M.H.; Lee, J.J.; Ahn, H.J. The effect of fluvastatin on cardiac fibrosis and angiotensin-converting enzyme-2 expression in glucose-controlled diabetic rat hearts. Heart Vessels 2017, 32, 618-627. [CrossRef] [PubMed]

193. Sasidhar, M.V.; Chevooru, S.K.; Eickelberg, O.; Hartung, H.P.; Neuhaus, O. Downregulation of monocytic differentiation via modulation of CD147 by 3-hydroxy-3-methylglutaryl coenzyme A reductase inhibitors. PLoS ONE 2017, 12, e0189701. [CrossRef]

194. Gao, J.; Gao, X.; Zhao, Z.; Pan, S. [Expression of cyclophilin A/CD147 in carotid atherosclerotic plaque and the intervention of atorvastatin]. Zhong Nan Da Xue Xue Bao Yi Xue Ban 2016, 41, 482-488. [CrossRef]

195. Wang, K.; Chen, W.; Zhou, Y.-S.; Lian, J.-Q.; Zhang, Z.; Du, P.; Gong, L.; Zhang, Y.; Cui, H.-Y.; Geng, J.-J.; et al. SARS-CoV-2 invades host cells via a novel route: CD147-spike protein. bioRxiv 2020. [CrossRef]

196. Chen, Z.; Mi, L.; Xu, J.; Yu, J.; Wang, X.; Jiang, J.; Xing, J.; Shang, P.; Qian, A.; Li, Y. Function of HAb18G/CD147 in invasion of host cells by severe acute respiratory syndrome coronavirus. J. Infect. Dis. 2005, 191, 755-760. [CrossRef]

197. Katsiki, N.; Banach, M.; Mikhailidis, D.P. Lipid-lowering therapy and renin-angiotensin-aldosterone system inhibitors in the era of the COVID-19 pandemic. Arch. Med. Sci. 2020, 16, 485-489. [CrossRef]

198. Guo, J.; Huang, Z.; Lin, L.; Lv, J. Coronavirus Disease 2019 (COVID-19) and Cardiovascular Disease: A viewpoint on the potential influence of angiotensin-converting enzyme inhibitors/angiotensin receptor blockers on onset and severity of severe acute respiratory syndrome coronavirus 2 infection. J. Am. Heart Assoc. 2020, 9, e016219. [CrossRef]

199. Sommerstein, R.; Kochen, M.M.; Messerli, F.H.; Gräni, C. Coronavirus Disease 2019 (COVID-19): Do Angiotensin-converting enzyme inhibitors/angiotensin receptor blockers have a biphasic effect? J. Am. Heart Assoc. 2020, 9, e016509. [CrossRef]

200. Hanff, T.C.; Harhay, M.O.; Brown, T.S.; Cohen, J.B.; Mohareb, A.M. Is there an association between COVID-19 mortality and the renin-angiotensin system-a call for epidemiologic investigations. Clin. Infect. Dis. 2020. [CrossRef]

201. Hamming, I.; van Goor, H.; Turner, A.J.; Rushworth, C.A.; Michaud, A.A.; Corvol, P.; Navis, G. Differential regulation of renal angiotensin-converting enzyme (ACE) and ACE2 during ACE inhibition and dietary sodium restriction in healthy rats. Exp. Physiol. 2008, 93, 631-638. [CrossRef] [PubMed] 
202. Ferrario, C.M.; Jessup, J.; Chappell, M.C.; Averill, D.B.; Brosnihan, K.B.; Tallant, E.A.; Diz, D.I.; Gallagher, P.E. Effect of angiotensin-converting enzyme inhibition and angiotensin II receptor blockers on cardiac angiotensin-converting Enzyme 2. Circulation 2005, 111, 2605-2610. [CrossRef]

203. Ocaranza, M.P.; Godoy, I.; Jalil, J.E.; Varas, M.; Collantes, P.; Pinto, M.; Roman, M.; Ramirez, C.; Copaja, M.; Diaz-Araya, G.; et al. Enalapril attenuates downregulation of Angiotensin-converting enzyme 2 in the late phase of ventricular dysfunction in myocardial infarcted rat. Hypertension 2006, 48, 572-578. [CrossRef] [PubMed]

204. Li, Y.; Zeng, Z.; Cao, Y.; Liu, Y.; Ping, F.; Liang, M.; Xue, Y.; Xi, C.; Zhou, M.; Jiang, W. Angiotensin-converting enzyme 2 prevents lipopolysaccharide-induced rat acute lung injury via suppressing the ERK1/2 and NF- $\mathrm{KB}$ signaling pathways. Sci. Rep. 2016, 6, 27911. [CrossRef] [PubMed]

205. Vuille-dit-Bille, R.N.; Camargo, S.M.; Emmenegger, L.; Sasse, T.; Kummer, E.; Jando, J.; Hamie, Q.M.; Meier, C.F.; Hunziker, S.; Forras-Kaufmann, Z.; et al. Human intestine luminal ACE2 and amino acid transporter expression increased by ACE-inhibitors. Amino Acids 2015, 47, 693-705. [CrossRef]

206. Furuhashi, M.; Moniwa, N.; Mita, T.; Fuseya, T.; Ishimura, S.; Ohno, K.; Shibata, S.; Tanaka, M.; Watanabe, Y.; Akasaka, H.; et al. Urinary angiotensin-converting enzyme 2 in hypertensive patients may be increased by olmesartan, an angiotensin II receptor blocker. Am. J. Hypertens. 2015, 28, 15-21. [CrossRef]

207. Burrell, L.M.; Risvanis, J.; Kubota, E.; Dean, R.G.; MacDonald, P.S.; Lu, S.; Tikellis, C.; Grant, S.L.; Lew, R.A.; Smith, A.I.; et al. Myocardial infarction increases ACE2 expression in rat and humans. Eur. Heart J. 2005, 26, 369-375, discussion 322-364. [CrossRef]

208. Ferrario, C.M.; Jessup, J.; Gallagher, P.E.; Averill, D.B.; Brosnihan, K.B.; Ann Tallant, E.; Smith, R.D.; Chappell, M.C. Effects of renin-angiotensin system blockade on renal angiotensin-(1-7) forming enzymes and receptors. Kidney Int. 2005, 68, 2189-2196. [CrossRef]

209. Klimas, J.; Olvedy, M.; Ochodnicka-Mackovicova, K.; Kruzliak, P.; Cacanyiova, S.; Kristek, F.; Krenek, P.; Ochodnicky, P. Perinatally administered losartan augments renal ACE2 expression but not cardiac or renal Mas receptor in spontaneously hypertensive rats. J. Cell Mol. Med. 2015, 19, 1965-1974. [CrossRef] [PubMed]

210. Igase, M.; Strawn, W.B.; Gallagher, P.E.; Geary, R.L.; Ferrario, C.M. Angiotensin II AT1 receptors regulate ACE2 and angiotensin-(1-7) expression in the aorta of spontaneously hypertensive rats. Am. J. Physiol. Heart Circ. Physiol. 2005, 289, H1013-H1019. [CrossRef] [PubMed]

211. Zhong, J.C.; Ye, J.Y.; Jin, H.Y.; Yu, X.; Yu, H.M.; Zhu, D.L.; Gao, P.J.; Huang, D.Y.; Shuster, M.; Loibner, H.; et al. Telmisartan attenuates aortic hypertrophy in hypertensive rats by the modulation of ACE2 and profilin-1 expression. Regul. Pept. 2011, 166, 90-97. [CrossRef] [PubMed]

212. Ishiyama, Y.; Gallagher, P.E.; Averill, D.B.; Tallant, E.A.; Brosnihan, K.B.; Ferrario, C.M. Upregulation of angiotensin-converting enzyme 2 after myocardial infarction by blockade of angiotensin II receptors. Hypertension 2004, 43, 970-976. [CrossRef]

213. Burchill, L.J.; Velkoska, E.; Dean, R.G.; Griggs, K.; Patel, S.K.; Burrell, L.M. Combination renin-angiotensin system blockade and angiotensin-converting enzyme 2 in experimental myocardial infarction: Implications for future therapeutic directions. Clin. Sci. (Lond.) 2012, 123, 649-658. [CrossRef] [PubMed]

214. Karam, C.N.; Nuwayri-Salti, N.; Usta, J.A.; Zwainy, D.S.; Abrahamian, R.E.; Al Jaroudi, W.A.; Baasisri, M.J.; Abdallah, S.M.; Bitar, K.M.; Bikhazi, A.B. Effect of systemic insulin and angiotensin II receptor subtype-1 antagonist on endothelin-1 receptor subtype(s) regulation and binding in diabetic rat heart. Endothelium 2005, 12, 225-231. [CrossRef] [PubMed]

215. Wösten-van Asperen, R.M.; Lutter, R.; Specht, P.A.; Moll, G.N.; van Woensel, J.B.; van der Loos, C.M.; van Goor, H.; Kamilic, J.; Florquin, S.; Bos, A.P. Acute respiratory distress syndrome leads to reduced ratio of ACE/ACE2 activities and is prevented by angiotensin-(1-7) or an angiotensin II receptor antagonist. J. Pathol. 2011, 225, 618-627. [CrossRef]

216. Keidar, S.; Gamliel-Lazarovich, A.; Kaplan, M.; Pavlotzky, E.; Hamoud, S.; Hayek, T.; Karry, R.; Abassi, Z. Mineralocorticoid receptor blocker increases angiotensin-converting enzyme 2 activity in congestive heart failure patients. Circ. Res. 2005, 97, 946-953. [CrossRef]

217. Epelman, S.; Tang, W.H.; Chen, S.Y.; Van Lente, F.; Francis, G.S.; Sen, S. Detection of soluble angiotensin-converting enzyme 2 in heart failure: Insights into the endogenous counter-regulatory pathway of the renin-angiotensin-aldosterone system. J. Am. Coll Cardiol. 2008, 52, 750-754. [CrossRef] 
218. Ding, W.; Li, X.; Wu, W.; He, H.; Li, Y.; Gao, L.; Gan, L.; Wang, M.; Ou, S.; Liu, J. [Aliskiren inhibits angiotensin II/angiotensin 1-7(Ang II/Ang1-7) signal pathway in rats with diabetic nephropathy]. Xi Bao Yu Fen Zi Mian Yi Xue Za Zhi 2018, 34, 891-895.

219. Oudit, G.Y.; Kassiri, Z.; Jiang, C.; Liu, P.P.; Poutanen, S.M.; Penninger, J.M.; Butany, J. SARS-coronavirus modulation of myocardial ACE2 expression and inflammation in patients with SARS. Eur. J. Clin. Investig. 2009, 39, 618-625. [CrossRef]

220. Patel, V.B.; Bodiga, S.; Fan, D.; Das, S.K.; Wang, Z.; Wang, W.; Basu, R.; Zhong, J.; Kassiri, Z.; Oudit, G.Y. Cardioprotective effects mediated by angiotensin II type 1 receptor blockade and enhancing angiotensin 1-7 in experimental heart failure in angiotensin-converting enzyme 2-null mice. Hypertension 2012, 59, 1195-1203. [CrossRef] [PubMed]

(C) 2020 by the authors. Licensee MDPI, Basel, Switzerland. This article is an open access article distributed under the terms and conditions of the Creative Commons Attribution (CC BY) license (http://creativecommons.org/licenses/by/4.0/). 